\title{
Employment versus Wage Adjustment and the U.S. Dollar
}

\author{
by \\ José Manuel Campa \\ and \\ Linda S. Goldberg
}

EC-99-07 


\title{
Employment versus Wage Adjustment and the U.S. Dollar
}

\begin{abstract}
$\underline{\text { ABSTRACT }}$
Using two decades of annual data, we explore the links between real exchange rates and employment, wages and overtime activity in specific U.S. manufacturing industries. Across two-digit industry levels of aggregation, exchange rate movements do not have large effects on numbers of jobs or on hours worked. More substantial effects are picked up in industry wages, especially for industries characterized by low price-over-cost markup ratios, and in overtime wages and overtime employment. The industry-by-industry pattern of wage responsiveness is not strongly related to industry export orientation or changes in overall external orientation. Industries with low price-overcost markups and those with a less skilled workforce exhibit relatively larger employment elasticities but lower wage elasticities.
\end{abstract}

September 3, 1998

(revised April 23, 1999)

\author{
José Manuel Campa \\ Stern School of Business, N.Y.U. \\ and N.B.E.R.
}




\section{INTRODUCTION}

We know that exchange rates matter. The challenge is pinning down the exact channels for exchange rate effects and their range of specific implications for the real economy. This paper examines the effects of exchange rates on employment, wages, and overtime activity over the past twenty-five years for manufacturing industries of the United States. Two economic trends have been persistent during this period: an increase in the external orientation of the U.S. manufacturing sector and large movements in exchange rates. The goal of this paper is to identify the effects that these exchange rate movements have had on U.S. manufacturing jobs and wages given the changing external orientation of U.S. industries.

Our evidence supports a statistically significant response of industry wages to exchange rate changes, and a very weak statistical relationship between numbers of jobs and employment and dollar movements. The average wage elasticity to a permanent exchange rate change for all manufacturing during this period was 0.04 , while the average employment elasticity was only 0.01. We also identify two particular industry features that are associated with the relative importance of exchange rates: the industry competitive structure, and the skill level of its labor force. Low-markup industries -industries like textiles, lumber and wood products, and primary metal or fabricated metal products- have a more significant response to exchange rate than highmarkup industries. The wage elasticities of response are larger in industries that are more exportoriented and are reduced (and can even turn negative) for industries that rely more heavily on imported productive inputs. Industries with a higher proportion of college-educated workers in their labor force also have higher wage and lower employment elasticities to exchange rates.

We also look at the effects of exchange rate movements on overtime activity in these industries. We find statistically significant effects of exchange rate changes on overtime hours and overtime wages. The elasticity of overtime wage to exchange rate changes is small and negative for most industries, averaging -0.12. The overtime hour and wage elasticities are higher in industries with more skilled workforces and in low-markup industries.

Our results -- on significant wage response and weak employment response -- differ from those of earlier studies linking exchange rates to labor markets. Branson and Love (1987, 1988), using data for the 1970s and early 1980s, found that real exchange rate movements influenced 
manufacturing sector employment: dollar appreciations (depreciations) were associated with significant output and employment losses across mainly durable goods sectors. Revenga (1992), using a sample of three and four digit manufacturing industries over the 1977 to 1987 period, found that exchange rates have significant implications for employment in the United States, and smaller but still significant effects on wages. The estimates came from a sub-sample of manufacturing industries and focused on the effects of import competition into the United States: the higher the import share of an industry, the more an import price decline or dollar appreciation hurt domestic labor markets. ${ }^{1}$

Instead, using 2-digit industry data for all of manufacturing for a longer sample period -the early 1970s through mid -1990s-- we find that industry wages are considerably more responsive than jobs (and hours worked) to exchange rate movements. We also show how this wage responsiveness has been growing over time as U.S. industries become more export oriented. The growth of imported input use by producers provides some offset to the pressures from the export channel partially offsetting its overall effect. More significant wage effects are apparent in industries that have lower price-over-cost markups and with relatively less-skilled workforces. These industries are closer to perfect competition and have production biased toward durable goods. Patterns of significant employment responsiveness are different: these employment effects are concentrated in a much smaller group of industries. Robustness checks confirm these results. These checks are done in alternative ways, including via the use of industry-specific real exchange rates and via industry-data disaggregated at the 4-digit level.

We also consider labor market adjustment via another margin, through industry use of and payment for overtime activity. We find a qualitatively important role of currency movements.

\footnotetext{
${ }_{1}$ International evidence on the effects of exchange rates on labor markets is provided in Dekle (1996), who focuses on Japan, and in Burgess and Knetter (1997), who focus on the G-7 countries (the United States, Germany, the United Kingdom, Japan, Canada, France, and Italy). Dekle shows that exchange rates significantly influence employment in Japan, with larger implications observed in industries with higher export shares. Brunello (1990) provides further insights regarding Japanese labor market adjustments. Burgess and Knetter also focus exclusively on employment adjustment to exchange rate movements, and emphasis two themes. First, they confirm differences across countries in employment elasticities with respect to exchange rates and different industry speeds of employment adjustment. Second, they assert that those industries in which a high degree of pricing to market occurs exhibit weaker linkages between exchange rate and employment fluctuations.
} 
Changes in the U.S dollar significantly affect overtime wages and overtime hours, especially in high markup industries and industries with more skill-intensive production. Industry unionization rates and capital intensity are uncorrelated with industry rankings of the elasticity of wage, employment or overtime activity response to the exchange rate.

Our conclusions on wages are quantitatively similar to those reported by Revenga (1992) while our employment estimates differ with both the early Branson and Love study and the more recent findings by Revenga. Differences in the estimation intervals across the studies do not explain these differences. ${ }^{2}$ Two other differences in approach, one methodological and one related to data, may explain the starkly different findings on employment response across this group of related papers.

On the methodology front, our work focuses on the different channels of exchange rate exposure of an industry while the previous studies focus on one particular channel, import competition. For example, Revenga's motivation and sample of industries are driven by the goal of estimating the effects that import competition in the United States had on U.S. labor markets. Instead, we stress the importance of decomposing the sources of currency exposure of an industry into its three major components. An industry exposure to exchange rates can arise from its reliance on export revenues, imported inputs into production, and, as highlighted in the previous work, from import competition. ${ }^{3}$ A complete understanding of the effects of exchange rates on economic activity requires an econometric analysis that accounts for these three different forms of

2 We estimated our equations for the intervals used in the Branson-Love and in the Revenga studies. Our empirical results for the 1972 to 1984 interval, used in Branson and Love, were not qualitatively different from our full sample results. For the 1977 to 1987 interval, used in Revenga, our wage significance results continued to be similar to what is reported in the paper. Even in this limited sample period, we find that both employment and hours have weak statistical relationships with exchange rates. Any significance that we detect works in the opposite direction - suggesting that a dollar depreciation reduces rather than stimulates manufacturing employment.

${ }^{3}$ In practice, since industry import penetration and use of imported inputs are so highly correlated, these separate transmission channels cannot be identified empirically. 
exposure and for their evolution overtime. ${ }^{4}$ Indeed, we find that this decomposition of channels is important for observing the evolving pattern of industry wage responsiveness to exchange rates.

The second important difference between the current paper and the previous work relates to differences in the data used. Our coverage of industries is broader in scope, since it includes all the 2-digit manufacturing sectors. A potential concern could be that this higher level of industry aggregation misses some of the responsiveness and adjustments that may occur within the more disaggregated industry data, such as the data from 3 and 4-digit industries used in Revenga (1992). If most of the employment reallocation occurs among 4-digit industries within a single 2digit industry, then one should expect very low employment elasticities to exchange rates at the 2digit level while there is substantial employment turnover within that industry. Low net employment fluctuations in the 2-digit industry could be consistent with high rates of job creation and destruction within the industry. Davis and Haltiwanger (1997) provide some evidence in this direction in their documentation of the substantial allocative employment effects of oil price shocks. ${ }^{5}$ These findings suggest that the more disaggregated the data, the more likely that net employment will appear to respond to industry shocks.

These issues of aggregation may not mask the significant wage effects of dollar movements. Even when there is job destruction and hiring within a sector, worker earnings can still adjust substantially. Kletzer (1998, Table 6) provides insightful data relevant to this point: a matrix of post-job displacement employment by sector between 1979 and 1994 shows that displaced workers are most likely to find new positions within their old sector, and this reemployment is almost always (on average) associated with mean wage declines.

We perform robustness checks on our 2-digit results by using the closest available series at a 4-digit level of industry disaggregation. Regressions over the 4-digit industry data (representing the 4504 -digit industries that aggregate to the 20 2-digit industry groups) confirm that the wage and employment elasticities on average continue to be small but significantly responsive to

\footnotetext{
${ }^{4}$ For example, see Campa and Goldberg (1995 and forthcoming) on investment and exchange rates, Sheets (1992) on profits and exchange rates, and Allayanis and Ehrig (1998) on stock prices and exchange rates.

5 Using information at the plant level from census data, they show that there is job churning in response to oil shocks and the amount of this churning differs across the 4-digit versus 2-digit level of industry aggregation of
} 
exchange rate movements. Data on overtime activity are not available at this level of disaggregation, so we cannot undertake the analyses of series comparable to those reported at the 2-digit industry level.

In the next section we develop a simple model of dynamic labor market equilibrium that explicitly incorporates the channels for exchange rate effects. Through the demand side of the labor market, we show that industry features - including trade orientation, costs of adjustment, and competitive structure -- can influence the level and timing of labor market adjustments to exchange rates. All else equal, optimal adjustments to labor demand in response to exchange rates movements are increasing in the industry export orientation and import competition. These effects are more ambiguously related to an industry's use of imported inputs because domestic and imported inputs may be either substitutes or complements in the production function.

The theory presented in Section II also tracks how other industry features should systematically affect the level and mix of industry wage versus employment adjustment, if these features are correlated with labor demand and supply elasticities or the costs of employment adjustment to shocks. ${ }^{6}$ Among these features are the mix of skilled and less-skilled workers and the industry unionization rates, which may influence the cost of adjusting the labor force. In addition, industry structure should matter: more "competitive" industries (i.e. those with lower price-over-cost markups) are expected to have more responsive labor demand than more oligopolistic industries. ${ }^{7}$ The remainder of the paper, Sections III and IV, describes the data and provides the results from the empirical estimation of the effects of exchange rates on industry wages, employment, and overtime activity in the United States. Section V concludes.

\section{Labor Markets and Exchange Rates}

employment data. At the 2-digit level, within manufacturing sector adjustment accounts for 67 percent of the total job re-allocation. At the 4-digit level, however, within sector reallocation is only 45 percent of the total.

6 Hammermesh (1993, chapter 7) provides a survey of related studies.

7 This relationship between industry markups and degrees of responsiveness to exchange rates already has been documented in the context of industry investment and profitability data for the United States and Japan in Campa and Goldberg, (forthcoming); Allayanis and Ehrig (1998), and Bodnar, Dumas, and Marston (1998). 
We present a simple dynamic model of labor market equilibrium, wherein within each year some combination of employment and wage adjustments equilibrate labor markets in response to shocks. Exchange rate shocks influence labor demand by affecting the marginal revenue product of through changes in its domestic and foreign sales and the cost of imported inputs into the production process. The elasticity of marginal revenue product with respect to exchange rates depends on industry pass-through elasticities, i.e. the price elasticities with respect to exchange rates in both domestic and foreign markets. Theoretically, these coefficients should be sensitive to industry trade orientation and to industry competitive structure (for example, see Dornbusch 1987, Marston 1990, and Bodnar, Dumas and Marston 1998).

Industry structure matters because producer profitability and labor demand will be most affected by exchange rates in industries where producers have little ability to counter shocks by exerting price-setting abilities. ${ }^{8}$ The trade orientation of the industry also matters, since greater export orientation increases labor demand sensitivity and the positive stimuli from a dollar depreciation. More intensive imported input use can either increase or reduce labor demand sensitivity, depending on the assumed structure of production activity and product demand. Other industry characteristics, including those that alter an industry's costs of adjusting it's workforce, will change the timing of wage versus employment response, and the degree of short-term reliance on overtime work efforts.

A. Exchange Rates and Labor Demand: Profit maximizing producers sell to both domestic and foreign markets and are faced with a variety of demand shocks. Producer decisions depend on the future paths of all variables influencing profitability. In our context, the unknowns to the producer are aggregate demand in domestic and foreign markets, denoted $y$ and $y^{*}$, and the exchange rate, $e$, defined as domestic currency per unit of foreign exchange. Production uses three factors: domestic labor $L$, domestic capital and other domestic inputs $Z$, and imported productive inputs, $Z^{*}$. Respective factor prices are denoted by $w, s$, and $e s^{*}$. Our focus in the

\footnotetext{
8 Industry stock prices and investment responses to exchange rates across various international markets are more sensitive in low price-over-cost markup industries Allayanis and Ehrig (1998) and Bodnar, Dumas, and Marston (1998) provide preliminary evidence on stock prices. Campa and Goldberg (1995 and forthcoming) provide evidence on investment responses across countries.
} 
paper is on one factor input, domestic labor. We model changes in the use of domestic input subject to a partial adjustment cost. For simplicity, we assume that labor is a homogeneous input into production and that the levels of capital and foreign inputs can be fully adjusted in the short run with no additional costs. ${ }^{9}$

Within an industry, the representative producer chooses factor inputs and total output in order to maximize the expected present value of the flow of current and future profits, $\pi$, (equation 1). The optimization is subject to the constraints posed by its production structure (equation 2), given its product demands in domestic and foreign markets (equation 3) and the additional costs involved in changing its level of domestic labor (equation 4). Profits are garnered from the sales in the home market, $q$, and the sales in the foreign market, $q^{*}$. In addition, home and foreign sales depend on aggregate demand conditions in the respective markets, i.e. on $y$ and $y^{*}$.

$\pi\left(y_{t}, y^{*}{ }_{t}, e_{t}\right)=\max _{Q_{t}, L_{t}, Z^{*}{ }_{t}, Z} \sum_{t=0}^{\infty} \phi_{t}\left[\begin{array}{l}p\left(q_{t}: y_{t}, e_{t}\right) q_{t} \\ +e_{t} p *\left(q{ }_{t}: y{ }_{t}, e_{t}\right) q^{*}{ }_{t} \\ -w_{t} L_{t}-e_{t} s{ }_{t} Z^{*}{ }_{t}-s_{t} Z_{t} \\ -c\left(\Delta L_{t}\right)\end{array}\right]$

subject to $Q=q+q^{*}, Q=L^{\beta} Z^{*}{ }^{* \alpha} Z^{1-\alpha-\beta}$,

and $\quad p(q: y, e)=a(y, e) q^{-1 / \eta}$ and $e p *\left(q^{*}: y^{*}, e\right)=a^{*}\left(y^{*}, e\right) q^{*-1 / \eta^{*}}$

and $\quad c\left(\Delta L_{t}\right)=w_{t} \frac{b}{2}\left(L_{t}-L_{t-1}\right)^{2}$

The time discount factor is defined by $\phi_{t}=\prod_{\tau} \delta^{\tau}$. In equations (2) and (3) we have dropped the period $t$ time subscripts for convenience. . In equation (2), a Cobb-Douglas production structure is assumed for simplicity, but our main results also will hold under a more general CES production structure.

\footnotetext{
9 The assumption of homogeneous labor precludes us from considering the linkage between exchange rate movements and the wage gap between skilled and unskilled workers.
} 
In equation (3) the parameters $\eta$ and $\eta^{*}$ are, respectively, the domestic and foreign product demand elasticities facing producers in their own industries. The demand curves in domestic and foreign markets include multiplicative demand shifters, $a(y, e)$ and $a^{*}\left(y^{*}, e\right)$, which allow for independent roles of local market real income and of exchange rates. Exchange rates influence demand by potentially leading to shifts in the relative price of home products versus those of foreign competitors, ${ }^{10}$ and therefore, affecting the residual demand faced by the domestic firm .

In equation (4) the costs of adjusting an industry's labor input, assumed to be quadratic, are fixed per worker in wage units, reflecting labor force adjustment costs that rise in proportion to wages. The parameter $b$ reflects the costs of adjustment of the level of labor and should be viewed as being industry specific. The use of a quadratic formulation for adjustment costs is standard in the literature and should not be seen as an attempt to closely represent reality since it implies that firing and hiring costs are identical. However, it should be interpreted as a convenient simplification since it allows a straightforward empirical implementation of the labor demand equation.

The solution to the firm's optimal labor demand problem is a dynamic equation. This equation is derived from the first-order conditions in each factor, and equates the marginal revenue product from an additional unit of labor today to the marginal cost of that unit for the firm. The marginal cost for the firm of an additional unit of labor has three components: 1) the additional wage that has to be paid; 2) the costs incurred in adjusting the level of input use by that additional unit; and 3) the present value of the change in additional costs of changing the optimal labor amount in the future by the firm. The resulting first-order condition has the form:

$$
p\left(q_{t}, e_{t}\right)\left(1+\eta^{-1}\right) \frac{\delta f}{\delta L} t=w_{t}+b\left(w_{t}\left(L_{t}-L_{t-1}\right)+\delta w_{t+1}\left(L_{t+1}-L_{t}\right)\right)
$$

Equation (5) is a second order difference equation in units of labor. As a step toward solving this equation, it is convenient at this point to define a new variable, $\tilde{L}$, as that level of input use which would be the optimal amount chosen by the firm in the absence of adjustment

\footnotetext{
10 Our demand structure here is similar to that of Burgess and Knetter (1996).
} 
costs, i.e. at $b=0$. Nickell (1986) shows that, under reasonable assumptions, the stable root of the resulting fundamental equation implies a partial adjustment path of optimal employment:

$$
L_{t}=\mu L_{t-1}+(1-\mu)(1-\delta g \mu) \sum_{j=0}^{\infty}(\delta g \mu)^{j} \tilde{L}_{t+j}
$$

where $g$ denotes expected real wage growth rate (assumed to be a constant), and $\mu$ denotes the stable root of the fundamental equation for employment. $\mu$ is increasing in $b$ and decreasing in the wage sensitivity of marginal revenue product.

Equation (6) shows that the target level of current employment is simply a convex combination of last period's employment and a weighted sum of all future values of $\tilde{L}$. The weights on future values of $\tilde{L}$ decline geometrically. The "speed of adjustment" of labor demand to the levels that would exist in the absence of costly adjustment is given by $1-\mu$. This weighting structure is intuitive: changes in employment will be slower in industries with large adjustment costs and faster in those industries with more wage sensitive marginal revenue product.

At this point, we need to elaborate on the solution for $\tilde{L}$ at any date $t$. The solution to the first-order conditions of the producer problem, after invoking Euler's theorem, shows that optimal labor demand by a firm in the absence of adjustment costs is:

$$
\tilde{L}_{t}=\frac{Q}{w_{t}}\left(\begin{array}{l}
p\left(q_{t}: y_{t}, e_{t}\right)\left(1+\eta^{-1}\right)\left(1-\chi_{t}\right) \\
+e_{t} p *\left(q *_{t}: y *_{t}, e_{t}\right)\left(1+\eta *^{-1}\right)\left(\chi_{t}\right) \\
-e_{t} s *_{t} \alpha\left(\frac{\partial Q_{t}}{\partial Z *_{t}}\right)^{-1}-s_{t}(1-\alpha-\beta)\left(\frac{\partial Q_{t}}{\partial Z_{t}}\right)^{-1}
\end{array}\right)
$$

Equation (7) shows that optimal labor demand in the absence of adjustment costs depends on the structure of and importance to the firm of both domestic and foreign demand, and on the substitutability between productive factors measured alongside their costs.

Our goal is to use the optimal labor demand defined by equations (6) and (7) to derive a workable and intuitive relationship between exchange rates -- a variable assumed exogenous to the firm -- and labor demand. Recall from our framework in equation (1) that there are three 
potential sources of shocks that the firm faces, through aggregate domestic demand, through foreign demand, and through the exchange rate. Our emphasis here is on the effect of changes in the exchange rates. Differentiating (7) with respect to exchange rates, we derive the following elasticity:

$$
\frac{\partial \tilde{L}}{\partial e} / \frac{\tilde{L}}{e}=\frac{1}{\beta}\left(\begin{array}{l}
p(\cdot)\left(1+\eta^{-1} \eta^{p e}+\chi\left(e p^{*}(\cdot)\left(1+\eta^{*-1}\right)\left(1+\eta^{p^{* e}}\right)-p(\cdot)\left(1+\eta^{-1}\right) \eta^{p e}\right)\right. \\
-\alpha e s *(\partial Q / \partial Z *)^{-1}
\end{array}\right)
$$

where $\chi$ represents the share of export sales in revenues, $\chi^{i}=p^{* i} q^{* i} /\left(p^{i} q^{i}+p^{* i} q^{* i}\right)$. $\eta^{p, e}$ and $\eta^{p^{* e}}$ are domestic and foreign price elasticities with respect to exchange rates. These price elasticities are best understood in the context of theories of exchange-rate pass through. For monopolistically competitive markets, the domestic price elasticity with respect to exchange rates is proportional to import penetration of domestic markets, i.e. $\eta^{p, e} \propto k M$. Moreover, the foreign price elasticity with respect to exchange rates is proportional to domestic penetration of those markets (Dornbusch 1989). We use these relationships, assume that the law of one price holds ex ante, and assume that the product of two trade share terms is approximately equal to zero $\left(\chi M=0\right.$ and $\left.\chi M^{*}=0\right) .{ }^{11}$ Under these assumptions there is a very clean expression for the elasticity of $\tilde{L}$ with respect to exchange rates:

$$
\frac{\partial \tilde{L}}{\partial e} / \frac{\tilde{L}}{e}=\frac{p}{\beta}\left(\left(1+\eta^{-1}\right) k M+\left(1+\eta^{*-1}\right) \chi-\left(\partial Q / \partial Z^{*}\right)^{-1} \alpha\right)
$$

Equation (9) clearly shows the three channels through which optimal labor demand is exposed to exchange rate movements, and the key roles played by industry features and the producer's external orientation. The three transmission channels are through industry import penetration $(M)$, export orientation $(\chi)$, and imported input use $(\alpha)$. All else equal, from the derived elasticity of labor demand (under costless adjustment) to exchange rates we observe specific ways in which industry features magnify or reduce this elasticity: $i$ ) When the production technology is labor intensive (i.e. $\beta$ is high), labor demand is less responsive to exchange rates; ii) Greater import penetration of domestic markets raises the sensitivity of labor demand to exchange 
rates; iii) Higher export orientation of an industry increases the sensitivity of its labor demand to exchange rates; and $i v$ ) Greater reliance on imported inputs into production (higher $\alpha$ ) reduces labor demand following a stronger domestic currency (since domestic currency depreciation raises the cost of one of the factors of production).

Equation (9) also explicitly shows that the role of exchange rates in labor demand is strongest in industries that impart pricing power to firms. This occurs when $k$ is high and when demand elasticities are low. Thus, all else equal, labor demand is most sensitive to exchange rates if foreign firms have pricing power in local markets. Product demand elasticities - in both domestic and foreign markets - also are important. The higher the price elasticity of demand facing producers, and the lower the implied price-over-cost markups in the industry, the more responsive will be labor demand to exchange rates.

Using equations (7) and (9), and log-linearizing, optimal labor demand in the absence of adjustment costs can be expressed in reduced form as:

$$
\tilde{L}_{t}=c_{0}+c_{1} y_{t}+c_{2} y_{t}^{*}+\left(c_{3,0}+c_{3,1} \chi+c_{3,2} M+c_{3,3} \alpha\right) e_{t}+c_{4} w_{t}+c_{5} s_{t}+c_{6} s_{t}^{*}
$$

where all variables other than $\chi, M$, and $\alpha$ are defined in logs.

We next use equations (6) and (10) to solve for optimal labor demand at any point in time. Recall that equation (6) shows that the reaction of employment today to an exchange rate shock depends not only on the current shock, but also on all future expected changes of the exchange rate through their effects on $\tilde{L}_{\mathrm{t}+\mathrm{j}}$. The actual structure of labor demand of any specific shock depends on whether the shock is permanent or transitory. A general form for optimal labor demand is given by a reduced form expression:

$$
L_{t}^{d}=\mu L_{t-1}+(1-\mu)\left(\begin{array}{l}
c_{0}+c_{1} y_{t}+c_{2} y_{t}^{*}+\left(c_{3,0}+c_{3,1} \chi+c_{3,2} M+c_{3,3} \alpha\right) e_{t} \\
+c_{4} w_{t}+c_{5} s_{t}+c_{6} s_{t}^{*}
\end{array}\right)
$$

\footnotetext{
${ }^{11} \mathrm{We}$ also assume that the foreign real input cost equals 1 , i.e that $\mathrm{s} / \mathrm{p} *=1$.
} 
where the actual parameters on the shocks change with the degree of permanence of the shock. A shock that is transitory will have a much smaller impact than a shock that is viewed as permanent. For instance, a purely transitory movement in the exchange rate gives rise to a change in labor demand that is $(1-\delta g \mu)<1$ the size of the effect from a permanent exchange rate movement. ${ }^{12}$

B. Exchange Rates and Labor Supply: To complete our description of the labor market and move towards an understanding of observable labor market outcomes - i.e. on industry wages and employment or hours -- we also must introduce labor supply conditions. Labor supply has been the focal point of a vast amount of research with a micro-economic orientation. However, much of the emphasis of that literature - on changes in market demographics and household structure is orthogonal to our emphasis on exchange rate movements. For simplicity we treat labor supply as an increasing function of wages and decreasing function of income, wherein the size of the supply sensitivities depend on worker preferences and characteristics.

$$
L_{t}^{s}=a_{o}+a_{1} w_{t}+a_{2} y_{t}
$$

Setting labor demand (equation 11) equal to labor supply (equation 12), and solving the simultaneous equations for employment and wages yields the system of equations given by (13a13b) for any industry $i$ :

$$
\begin{aligned}
& w_{t}^{i}=\omega_{0}^{i}+\omega_{2} y_{t}+\omega_{3} y_{t}^{*}+\omega_{4} s_{t}+\omega_{5} s_{t}^{*}+\left(\omega_{6,0}^{i}+\omega_{6,1}^{i} \chi^{i}+\omega_{6,2}^{i} M^{i}+\omega_{6,3}^{i} \alpha^{i}\right) \cdot e_{t}^{i}+\omega_{7}^{i} L_{t-1}^{i} \\
& L_{t}^{i}=\lambda_{0}^{i}+\lambda_{2} y_{t}+\lambda_{3} y_{t}^{*}+\lambda_{4} s_{t}+\lambda_{5} s_{t}^{*}+\left(\lambda_{6,0}^{i}+\lambda_{6,1}^{i} \chi^{i}+\lambda_{6,2}^{i} M^{i}+\lambda_{6,3}^{i} \alpha^{i}\right) \cdot e_{t}^{i}+\lambda_{7}^{i} L_{t-1}^{i}
\end{aligned}
$$

From this system of equations we have key insights into features of the equilibrium wage and employment response to shocks. ${ }^{13}$ Specifically, (i) Industries with higher labor supply

\footnotetext{
12 A pure transitory shock is defined as a shock to the exchange rate that is expected to be fully reversed the next period, i.e., the best predictor today of tomorrow's exchange rate was its value yesterday.

${ }^{13}$ In the appendix we provide the solution using the exact parameters of the labor supply and the labor demand equations.
} 
elasticity with respect to wages have smaller wage adjustments and larger employment adjustments; (ii) Industries with higher labor demand elasticity with respect to wages have smaller wage and employment responsiveness to shocks; (iii) Industries with less elastic product demands have more responsive wages and employment; (iv) The wage and employment effects of exchange rate movements are increasing in industry export orientation and home market import penetration; and $(v)$ The scale of wage and employment response to exchange rates has an ambiguous relationship with industry use of imported productive inputs.

\section{The Data and Regression Specification.}

The system of equations provided by (13a-13b) are the basis for our estimating equations. We use annual industry data for the U.S. labor market variables and the trade shares for the interval 1972 through 1995. Our equations are estimated in first differences, and include common time trends and industry dummy variables. We run the regressions using pooled groups of twodigit manufacturing industries, and separately for the individual manufacturing industries.

We have conducted our estimation using two alternative types of exchange rate series. The first type of series is a single real multilateral exchange rate index, defined as the dollars per foreign currency with U.S. trade weights on the bilateral exchange rates of individual country currencies. The second type of exchange rate series is industry-specific. In this case, we construct a set of industry-specific real exchange rates for exports and another set for imports, using in each case the partner weights given by the size of particular countries in the specific trade activity of each industry (i.e. see Goldberg and Tracy 1999. The weights are derived from the annual shares of U.S. imports and U.S. exports in each industry from the 19 major trading partners of the United States.) In the regressions, both types of real exchange rate measures yield qualitatively similar results. In our exposition, we present only the results using the single real multilateral exchange rate measure. ${ }^{14}$

Our regressions examine the effect of exchange rates entered into the regressions as independent variables, which has been the standard in this literature, and also examine the effects of exchange rates interacted with the industry-specific and time-varying channels of trade. This latter approach is predicted by the theory. Yet, while our theory spelled out three distinct interacted channels (exports, import competition and imported inputs), ultimately we use only two interacted channels in 
the regressions: (i) the export to production share in the industry, and (ii) the share of imported inputs into production costs (see Campa and Goldberg 1997). We limited ourselves to these two channels because of the high within-industry correlations between import penetration and imported input use.

The regressions also include the prices of two other inputs: capital and energy. We use the long-term interest rate, measured by the yield in long-term U.S. Government bonds, as a measure of the cost of capital. Real oil prices, measured by the average annual dollar price per barrel of crude petroleum reported by the International Monetary Fund, are used as our measure of energy prices. The net effect for labor demand of an increase in either of these two prices depends on the substitutability versus complementarities of each of these factors with labor. To the extent that technological substitution between that input and labor is possible, an increase in the input price leads to an increase in the demand for labor. To the extent that the factors are complements, the sign of this correlation will be negative.

Our measures of labor market activity are central to the empirical work. The model of labor market equilibrium in Section II did not specify the unit of observation for labor. Labor was a continuous input that could be adjusted by infinitesimal amounts as needed. Empirically, labor activity during a certain period can be measured by several proxies, such as the average number of employees or as the total number of hours worked by employees (including overtime effort). As surveyed by Hammermesh (1993), a number of factors determine whether a producer's response to stimuli is through hiring (firing) new workers or through an increase (decrease) in the number of hours that the existing staff work. These factors include: the nature of the shock (transitory versus permanent) ${ }^{15}$; the industry costs of hiring/ firing versus expanding/ contracting work effort; and the types of contracts signed with workers. The tendency toward the use of overtime employment instead of changes in the number of employees is expected to be higher when the shocks are temporary, hiring and firing costs are high, and the labor pool is more skilled or requires more job-specific skills.

Our analysis looks at the endogeneity of both employment and total hours worked in each 2-digit manufacturing industry, as well as at industry wages and measures of industry overtime activity. The employment series is the total number of non-farm employees in the industry, as

\footnotetext{
${ }^{14}$ Additional results are available upon request from the authors.

15 Stimuli perceived to be more permanent are expected to be reflected more often in altered workforce numbers than in overtime hours.
} 
reported by the Bureau of Labor Statistics. The total hours series is the product of the employment series and the reported average weekly hours in each industry. Our measure of wages per employee is the average hourly wage in each industry, constructed by dividing the total of wage and salary accruals to all employees in each industry by the number of non-farm employees. Overtime wage is defined as the difference between total average hourly wages and average hourly wages excluding overtime for production and non-supervisory workers as defined by the Bureau of Labor Statistics. Overtime hours are the average weekly overtime hours of production workers.

As detailed in Appendix A, Table 1, there is a fair amount of dispersion of wages and employment across industries and within industries over time. Wages are less variable within industries over time than across industries at points in time. The variability of wages across industries is almost four times higher than the average variability overtime of wages within each industry. Wage variability across industries is also higher than employment variability. Finally, industry overtime wages and employment are considerably more volatile than overall wages and employment.

Wage and employment variability across industries are also related to observable industry and worker characteristics. Wage variability across industries is positively correlated with the skill intensity of its workers, industry unionization rates, and industry capital intensity. High unionization rates are associated with higher wage and employment variability (both total and overtime) while industries with higher price-over-cost markups tend to have lower employment and wage variability.

For our analysis, we decompose exchange rate movements into their permanent versus transitory components to capture our expectation that regular labor demand should be most responsive to permanent movements in exchange rates. We use the decomposition first suggested by Beveridge and Nelson (1981) and later employed to exchange rate data by Huizinga (1987), Campbell and Clarida (1987), Cumby and Huizinga (1990), and Clarida and Gali (1994), among others. The procedure, described in the appendix, decomposes the real exchange rate series into a stationary component (the temporary component) and a nonstationary component (its permanent component). An analysis of the resulting variance decomposition shows that the temporary component of exchange rate changes accounts for only a small proportion of the variance of the real exchange rate series. The variance of the transitory component of the real exchange rate 
accounts for less than 40 percent of the total variability of the real exchange rates. ${ }^{16}$

Finally, we perform a series of tests using alternative data series as a form of robustness checks on our results. In the context of the 2-digit industry data, one alternative specification uses industry-specific export and import exchange rates (see Goldberg and Tracy, 1999) in lieu of the trade-weighted series in the basic regressions. The advantage of these series is that they more accurately represent the importance of the currencies of trade partners relevant for particular industries. The disadvantage of these series is that we are unable to adequately decompose such series into their permanent and transitory components.

Another form of robustness check relies on the use of 4-digit industry data, as opposed to the 2-digit series that we report. The limitation of these series is that the hours and wages (from the NBER Productivity Database) are only for production workers, as opposed to the broader group of workers for whom we have data at the 2-digit level. Moreover, the input-output classification of industries does not have a one-to-one correspondence with the 4-dfigit SIC classification. At this level of disaggregation, the employment measure is the total number of hours for production workers only (not of total employees as in the 2-digit data), from the NBER Productivity Database. Finally, the overtime employment and jobs data are not available at the 4digit level.

\section{EMPIRICAL RESULTS}

In this section we present the results of several types of regressions. The first sets of regressions consider the role of the exchange rates and other variables in moving industry labor market variables across pooled groups of industries. In addition to pooling across the full sample of manufacturing industries, we compare industry responses in High versus Low Markup industry groups. Specifically, this sample of industries is split according to the median level of average price-over-cost markup across the group of manufacturing industries. ${ }^{17}$ While levels of markups may change over time, the actual division of industries relative to a median markup is very stable.

\footnotetext{
16 This result is consistent with the finding in this literature that real exchange rate shocks tend to be permanent.

17 The "Low Markup" group of industries includes: primary metal products, fabricated metal products, transportation equipment, food and kindred products, textile mill products, apparel and mill products, lumber and wood products, furniture and fixtures, paper and allied products, petroleum and coal products, and leather and leather products.
} 
The second set of regressions are for individual industries. While industry-specific regressions are ultimately what one would want, they each have too few observations to fully stand on their own merits. For each industry we will show the effects of exchange rates on it's employment, hours, wages, and overtime activity.

\section{Pooled Industry Regressions.}

The estimated results from equations (13a) and (13b) are reported in Tables 1 and 2. Table 1 reports the estimated coefficients from using total industry wages, total hours employed, and total industry employment. For each dependent variable we report the results from pooling the full sample of manufacturing industries and from splitting the sample between high and low markup industry markups.

The specifications also include as regressors a set of industry dummies, the interest rate, ${ }^{18}$ the price of oil, the annual value of GDP, and the lagged values of our measure of employment for each industry. All variables other than lagged employment are expressed in log differences (except for the interest rate which is just in percentage differences). We allow for industry specific speeds of adjustment to shocks by letting the coefficient on lagged industry employment be industry specific (not reported).

Table 2 reports the estimated coefficients from analogous regressions using as the dependent variable the measures of industry overtime wage and overtime employment. These regressions are similar in format to those of Table 1 with two notable exceptions. First, we assume that since changes in the amount of overtime activity is a short-run, temporary practice, it is not subject to the same adjustment costs as changes in permanent employment. Therefore, we estimate a static model instead of a partial-adjustment model in the overtime regressions. This implies that changing the size of the labor force through (limited) use of overtime has no cost other than the corresponding wage. We then drop from the estimation the lagged level of industry employment as a regressor. Second, since the model is static the amount of overtime activity is independent of whether a given exchange rate shock is permanent or temporary. We use actual (not just permanent) movements in exchange rates as the right-hand-side regressor.

\footnotetext{
18 We also ran a full system of regressions using a 2SLS procedure wherein interest rates were instrumented. This instrumenting did not qualitatively change our exchange rate results.
} 
From Table 1 observe that permanent exchange rates have significant explanatory power with respect to industry wages in low-markup industries. A dollar depreciation increases the average wages in industries that are more heavily involved in export activity. As industry export orientation rises, so does the role of the dollar in slowing industry wage growth. Industry reliance on imported production inputs can reverse the stimuli to wages associated with dollar depreciations. All else equal, as an industry increases its reliance on imported inputs, dollar appreciations have a smaller role in wage growth restraint. Indeed, in industries with imported input shares exceeding their export shares, appreciations could potentially accelerate wage growth. The same sign pattern of effects of exchange rates on wages appear for the full sample of industries and for the sub-sample including high-markup industries. However, for neither of them can we reject the hypothesis that the estimated exchange rate effects are jointly insignificant.

The effects of a permanent exchange rate change on industry employment measures are much weaker. All of the individual exchange rate coefficients for total hours are statistically insignificant, although the F-test rejects the hypothesis of these coefficients being equal to zero for high-markup industries. In the specifications explaining the total number of employees, the coefficients on the export terms are statistically significant for the full and high markup samples, as well as the coefficient with imported inputs. However, this significance is most likely resulting from the colinearity among these exchange rate terms since for all samples the F-tests are unable to reject the null hypothesis of these coefficients being jointly different from zero. Given these results, the effects of exchange rate changes on these measures of employment activity in manufacturing industries is likely to be very small. ${ }^{19}$

The rest of the regressors show consistently significant results for all the different specifications. Increases in the prices of other inputs are consistently negatively correlated with industry wages and positively correlated with industry employment. Industry employment, as expected, is high when the economy is in a boom, i.e., when the level of GDP is high. Wages, however, appear to decrease in periods of high economic activity.

19 When industry-specific exchange rates are used (without decomposition into the permanent and transitory components), F-test results show that the pairs of exchange-rate changes enter significantly into all of the regressions that are analogous to those reported in Tables 1 and 2. 
Overtime wages and overtime employment both are more significantly affected by exchange rate movements than total wages and employment (Table 2). The F-tests easily reject the null hypothesis of no exchange rate effect in all cases, with the exception of overtime employment in high markup industries (which is only marginally rejected). Dollar depreciations significantly increase overtime wages in high-markup industries with large export orientation, and decrease overtime wages in those industries with a larger imported-input orientation. We observe an opposite sign pattern for low markup industries. The effects of exchange rates on overtime employment are more significant in low markup industries than in high-markup industries. 
Table 1.Permanent Exchange Rate Changes and U.S. Employment and Wages

\begin{tabular}{|c|c|c|c|c|c|c|c|c|}
\hline & $X_{\mathrm{it}-1} \Delta \mathrm{ER}_{\mathrm{t}}$ & $M_{\mathrm{it}-1} \Delta \mathrm{ER}_{\mathrm{t}}$ & $\Delta \mathrm{OIL}_{\mathrm{t}}$ & $\Delta$ RATE $_{\mathrm{t}}$ & $\Delta \mathrm{GDP}_{\mathrm{t}}$ & N. obs. & adj.R2 & F-test \\
\hline \multicolumn{9}{|l|}{ Change in Wages } \\
\hline \multirow[t]{2}{*}{ All industries } & & & $\begin{array}{l}-0.021^{*} \\
(0.006)\end{array}$ & $\begin{array}{l}-0.039^{*} \\
(0.014)\end{array}$ & $\begin{array}{l}-0.155^{* *} \\
(0.014)\end{array}$ & 439 & .11 & \\
\hline & $\begin{array}{l}1.094^{*} \\
(0.445) \\
\end{array}$ & $\begin{array}{l}-0.850 \\
(0.605)\end{array}$ & $\begin{array}{l}-0.020^{*} \\
(0.006)\end{array}$ & $\begin{array}{l}-0.040^{*} \\
(0.014)\end{array}$ & $\begin{array}{l}-0.135 \\
(0.083)\end{array}$ & 439 & .13 & 2.32 \\
\hline \multirow{2}{*}{$\begin{array}{l}\text { High Price-over- } \\
\text { Cost Markup } \\
\text { Industries }\end{array}$} & & & $\begin{array}{l}-.022 * \\
(.010) \\
\end{array}$ & $\begin{array}{l}-.042 * * \\
(0.023) \\
\end{array}$ & $\begin{array}{l}-0.063 \\
(0.133) \\
\end{array}$ & 197 & .13 & \\
\hline & \begin{tabular}{|l|}
1.034 \\
$(0.785)$
\end{tabular} & $\begin{array}{l}-1.032 \\
(1.703)\end{array}$ & $\begin{array}{l}-0.024^{*} \\
(0.010)\end{array}$ & $\begin{array}{l}-0.039 \\
(0.023)\end{array}$ & $\begin{array}{l}-0.096 \\
(0.133)\end{array}$ & 197 & .15 & 1.14 \\
\hline \multirow{2}{*}{$\begin{array}{l}\text { Low Price-over- } \\
\text { Cost Markup } \\
\text { Industries }\end{array}$} & & & $\begin{array}{l}-0.018^{*} \\
(0.007)\end{array}$ & $\begin{array}{l}-0.038^{*} \\
(0.017)\end{array}$ & $\begin{array}{l}-0.205^{*} \\
(0.104)\end{array}$ & 242 & .05 & \\
\hline & $\begin{array}{l}1.896^{*} \\
(0.963) \\
\end{array}$ & $\begin{array}{l}-1.296 * * \\
(0.802) \\
\end{array}$ & $\begin{array}{l}-0.020^{*} \\
(0.007) \\
\end{array}$ & $\begin{array}{l}-0.037 * \\
(0.017) \\
\end{array}$ & $\begin{array}{l}-0.226^{*} \\
(0.106) \\
\end{array}$ & 242 & .06 & $3.43 *$ \\
\hline \multicolumn{9}{|c|}{ Change in Total Hours } \\
\hline \multirow[t]{2}{*}{ All industries } & & & $\begin{array}{l}0.021^{*} \\
(0.006)\end{array}$ & $\begin{array}{l}0.027 * * \\
(0.014)\end{array}$ & $\begin{array}{l}1.565^{*} \\
(0.086)\end{array}$ & 439 & .53 & \\
\hline & \begin{tabular}{|l|}
-0.664 \\
0.478 \\
\end{tabular} & $\begin{array}{l}0.950 \\
0.653 \\
\end{array}$ & $\begin{array}{l}0.021^{*} \\
(0.006)\end{array}$ & $\begin{array}{l}0.027^{* * *} \\
(0.014)\end{array}$ & $\begin{array}{l}1.571^{*} \\
(0.087)\end{array}$ & 439 & .53 & 1.10 \\
\hline \multirow{2}{*}{$\begin{array}{l}\text { High Price-over- } \\
\text { Cost Markup } \\
\text { Industries }\end{array}$} & & & $\begin{array}{l}0.023^{*} \\
(0.008)\end{array}$ & $\begin{array}{l}0.048^{*} \\
(0.019) \\
\end{array}$ & $\begin{array}{l}1.441^{*} \\
(0.112)\end{array}$ & 197 & .55 & \\
\hline & \begin{tabular}{|l|}
-0.639 \\
$(0.700)$ \\
\end{tabular} & $\begin{array}{l}0.970 \\
(1.527) \\
\end{array}$ & $\begin{array}{l}0.024 * \\
(0.008) \\
\end{array}$ & $\begin{array}{l}0.048^{*} \\
(0.019) \\
\end{array}$ & $\begin{array}{l}1.456^{*} \\
(0.114) \\
\end{array}$ & 197 & .55 & $3.56^{*}$ \\
\hline \multirow{2}{*}{$\begin{array}{l}\text { Low Price-over- } \\
\text { Cost Markup } \\
\text { Industries }\end{array}$} & & & $\begin{array}{l}0.019^{*} \\
(0.008)\end{array}$ & $\begin{array}{l}0.009 \\
(0.021)\end{array}$ & $\begin{array}{l}1.680^{*} \\
(0.127) \\
\end{array}$ & 242 & .53 & \\
\hline & \begin{tabular}{|l|l|}
0.132 \\
$(1.195)$ \\
\end{tabular} & $\begin{array}{l}0.346 \\
(0.995) \\
\end{array}$ & $\begin{array}{l}0.019^{*} \\
(0.008) \\
\end{array}$ & $\begin{array}{l}0.010 \\
(0.021) \\
\end{array}$ & $\begin{array}{l}1.665^{*} \\
(0.129) \\
\end{array}$ & 242 & .52 & 0.67 \\
\hline \multicolumn{9}{|c|}{ Change in Number of Jobs } \\
\hline \multirow{2}{*}{ All industries } & & & $\begin{array}{l}0.026^{*} \\
(0.005)\end{array}$ & $\begin{array}{l}0.026^{*} \\
(0.012)\end{array}$ & $\begin{array}{l}1.226^{*} \\
(0.074)\end{array}$ & 439 & .53 & \\
\hline & \begin{tabular}{|l}
$-0.758^{* * *}$ \\
$(0.425)$ \\
\end{tabular} & $\begin{array}{l}1.136^{* *} \\
(0.582)\end{array}$ & $\begin{array}{l}0.027^{*} \\
(0.005)\end{array}$ & $\begin{array}{l}0.026^{*} \\
(0.012)\end{array}$ & $\begin{array}{l}1.23^{*} \\
(0.074)\end{array}$ & 439 & .54 & 2.00 \\
\hline \multirow{2}{*}{$\begin{array}{l}\text { High Price-over- } \\
\text { Cost Markup } \\
\text { Industries }\end{array}$} & & & $\begin{array}{l}0.026^{*} \\
(0.007)\end{array}$ & $\begin{array}{l}0.037^{*} \\
(0.018)\end{array}$ & $\begin{array}{l}1.085^{*} \\
(0.104)\end{array}$ & 197 & .51 & \\
\hline & \begin{tabular}{|l}
$-1.211 * *$ \\
$(0.656)$ \\
\end{tabular} & $\begin{array}{l}2.051 \\
(1.432)\end{array}$ & $\begin{array}{l}0.027^{*} \\
(0.007)\end{array}$ & $\begin{array}{l}0.035^{*} \\
(0.018)\end{array}$ & $\begin{array}{l}1.110^{*} \\
(0.105)\end{array}$ & 197 & .52 & 1.80 \\
\hline \multirow{2}{*}{$\begin{array}{l}\text { Low Price-over- } \\
\text { Cost Markup } \\
\text { Industries }\end{array}$} & & & $\begin{array}{l}0.077 * \\
(0.006) \\
\end{array}$ & $\begin{array}{l}0.016 \\
(0.017) \\
\end{array}$ & $\begin{array}{l}1.364 * \\
(0.103) \\
\end{array}$ & 242 & .54 & \\
\hline & \begin{tabular}{|l|}
0.748 \\
$(1.038)$ \\
\end{tabular} & $\begin{array}{l}0.037 \\
(0.859) \\
\end{array}$ & $\begin{array}{l}0.027^{*} \\
(0.006)\end{array}$ & $\begin{array}{l}0.017 \\
(0.017)\end{array}$ & $\begin{array}{l}1.338^{*} \\
(0.104) \\
\end{array}$ & 242 & .54 & 0.81 \\
\hline
\end{tabular}

- $\quad *$ significant at 5 percent. $* *$ significant at 10 percent. F-test is of the hypothesis that coefficients on exchange rate terms are jointly non-zero. Each regression also includes as explanatory variables a time dummy, industry dummies, and a two-period lag of employment (industry-specific) 
Table 2. Actual Exchange Rate Changes and U.S. Overtime Wages and Hours

\begin{tabular}{|c|c|c|c|c|c|c|c|c|}
\hline & $X_{\mathrm{it}-1} \Delta \mathrm{ER}_{\mathrm{t}}$ & $M_{\mathrm{it}-1} \Delta \mathrm{ER}_{\mathrm{t}}$ & $\Delta \mathrm{OIL}_{\mathrm{t}}$ & $\Delta \mathrm{RATE}_{\mathrm{t}}$ & $\Delta \mathrm{GDP}_{\mathrm{t}}$ & \#Obs. & $\operatorname{adj} . \mathrm{R} 2$ & F-test \\
\hline \multicolumn{9}{|c|}{ Change in Overtime Wages } \\
\hline \multirow[t]{2}{*}{ All Industries } & & & $\begin{array}{l}-0.089 * \\
(0.018)\end{array}$ & $\begin{array}{l}-0.084^{*} \\
(0.045)\end{array}$ & $\begin{array}{c}3.342 * \\
(0.251)\end{array}$ & 440 & .38 & \\
\hline & $\begin{array}{l}0.803 \\
(1.129)\end{array}$ & $\begin{array}{l}-1.595 \\
(1.641)\end{array}$ & $\begin{array}{l}-0.073^{*} \\
(0.019)\end{array}$ & $\begin{array}{l}-0.074 \\
(0.047)\end{array}$ & $\begin{array}{l}3.419 * \\
(0.258)\end{array}$ & 440 & .39 & $3.95 *$ \\
\hline \multirow{2}{*}{$\begin{array}{l}\text { High Price- } \\
\text { over-Cost } \\
\text { Markup } \\
\text { Industries } \\
\end{array}$} & & & $\begin{array}{l}-.062 * \\
(0.031)\end{array}$ & $\begin{array}{l}0.023 \\
(0.076)\end{array}$ & $\begin{array}{l}3.651 * \\
(0.416)\end{array}$ & 198 & .34 & \\
\hline & $\begin{array}{l}3.744 * * \\
(1.943)\end{array}$ & $\begin{array}{l}-7.445 * * \\
(4.506)\end{array}$ & $\begin{array}{l}-0.075^{*} \\
(0.032)\end{array}$ & $\begin{array}{l}0.034 \\
(0.077)\end{array}$ & $\begin{array}{l}3.498 * \\
(0.427)\end{array}$ & 198 & .35 & $4.10^{*}$ \\
\hline \multirow{2}{*}{$\begin{array}{l}\text { Low Price- } \\
\text { over-Cost } \\
\text { Markup } \\
\text { Industries } \\
\end{array}$} & & & $\begin{array}{l}-0.080 * \\
(0.023)\end{array}$ & $\begin{array}{l}-0.147^{*} \\
(0.055)\end{array}$ & $\begin{array}{l}3.218 * \\
(0.301)\end{array}$ & 242 & .44 & \\
\hline & $\begin{array}{l}-5.955^{*} \\
(2.430) \\
\end{array}$ & $\begin{array}{l}3.138 \\
(2.086) \\
\end{array}$ & $\begin{array}{l}-0.067 * \\
(0.023) \\
\end{array}$ & $\begin{array}{l}-0.168 * \\
(0.055) \\
\end{array}$ & $\begin{array}{l}3.393 * \\
(0.307) \\
\end{array}$ & 242 & .46 & $6.46^{*}$ \\
\hline \multicolumn{9}{|c|}{ Change in Overtime Employment } \\
\hline \multirow[t]{2}{*}{ All Industries } & & & $\begin{array}{l}-0.086^{*} \\
(0.020)\end{array}$ & $\begin{array}{l}-0.065 \\
(0.051) \\
\end{array}$ & $\begin{array}{l}3.326^{*} \\
(0.281)\end{array}$ & 440 & .31 & \\
\hline & $\begin{array}{l}0.581 \\
1.256 \\
\end{array}$ & $\begin{array}{l}-0.892 \\
1.826 \\
\end{array}$ & $\begin{array}{l}-0.064^{*} \\
(0.021)\end{array}$ & $\begin{array}{l}-0.047 \\
(0.052)\end{array}$ & $\begin{array}{l}3.419 * \\
(0.288)\end{array}$ & 440 & .32 & $5.25^{*}$ \\
\hline \multirow{2}{*}{$\begin{array}{l}\text { High Price- } \\
\text { over-Cost } \\
\text { Markup } \\
\text { Industries }\end{array}$} & & & $\begin{array}{l}-0.056^{* *} \\
(0.034)\end{array}$ & $\begin{array}{l}0.054 \\
(0.084)\end{array}$ & $\begin{array}{l}3.416^{*} \\
(0.465)\end{array}$ & 198 & .26 & \\
\hline & $\begin{array}{l}3.403 \\
(2.194)\end{array}$ & $\begin{array}{l}-5.714 \\
(5.093) \\
\end{array}$ & $\begin{array}{l}-0.068 * * \\
(0.035)\end{array}$ & $\begin{array}{l}0.071 \\
(0.081)\end{array}$ & $\begin{array}{l}3.248 * \\
(0.478)\end{array}$ & 198 & .32 & 2.92 \\
\hline \multirow{2}{*}{$\begin{array}{l}\text { Low Price- } \\
\text { over-Cost } \\
\text { Markup } \\
\text { Industries }\end{array}$} & & & $\begin{array}{l}-0.072 * \\
(0.026)\end{array}$ & $\begin{array}{l}-0.130^{*} \\
(0.061)\end{array}$ & $\begin{array}{l}3.382 * \\
(0.332)\end{array}$ & 242 & .41 & \\
\hline & $\begin{array}{l}-6.812^{*} \\
(2.655)\end{array}$ & $\begin{array}{l}3.953 * * \\
(2.274)\end{array}$ & $\begin{array}{l}-0.056^{*} \\
(0.026)\end{array}$ & $\begin{array}{l}-0.153 * \\
(0.062)\end{array}$ & $\begin{array}{l}3.575 * \\
(0.339)\end{array}$ & 242 & .42 & $6.57 *$ \\
\hline
\end{tabular}

- * significant at 5 percent level. ** significant at 10 percent level.

- F-test is of the hypothesis that coefficients on exchange rate terms are jointly non-zero.

- Each regression also includes a time trend, and industry dummies as explanatory variables. 


\section{Industry-Specific Estimates.}

The results reported above impose that the effects of all the explanatory variables be the same for all industries (with the exception of the constant term and lagged employment). It is reasonable to think that some of the underlying parameters in the model outlined in section two, such as the industry demand and cost elasticities, are industry specific. We have attempted to relax this restriction somewhat by splitting the sample between high and low-markup industries and, as seen in Tables 1 and 2, the estimated coefficients do differ. In this section we provide further insights in the differences in the exchange rate effects by industry.

There are two ways that we attempt to shed light on the industry-specific behavior of adjustment of employment and wages to exchange rate changes. First, we use the estimated exchange rate coefficients in Tables 1 and 2 for the low and high-markup samples and the average export share and imported input share of each industry during the sample period to calculate the industry-specific elasticities of response to an exchange rate shock. These elasticities, with constructed levels of statistical significance, are reported in Table 3. Second, we estimated our original wage and employment specifications separately for each industry using only the data for a given industry. The estimated coefficients from these regressions are reported in the appendix, in Tables A2 and A3.

Table 3 shows that the imputed labor market response elasticities to an exchange rate shock vary considerably across industries. An exchange rate depreciation results in an increase in wages (for 16 out of 20 industries) and employment (15 out of 20) in most manufacturing industries. On average, a 10 percent permanent dollar depreciation will result in an increase in manufacturing wages of 0.5 percent and will increase total employment (number of jobs) by about 0.1 percent. The effects of an exchange rate depreciation on Overtime activity tend to be negative for most industries and the variability is large across industries. However, its overall effect in the overall manufacturing sector seems also small. The average effect on overtime employment in manufacturing from a 10 percent dollar depreciation is around 0.46 percent, while overtime wages decline by about 1.3 percent. 


\section{Table 3: Implied Elasticities of Response of Changes in Industry Labor Market Variables}

Computed using average export and imported input shares, 1972-1995

\begin{tabular}{|c|c|c|c|c|c|}
\hline Industry & wages & $\begin{array}{c}\text { Total } \\
\text { Hours }\end{array}$ & $\begin{array}{l}\text { Total } \\
\text { jobs }\end{array}$ & $\begin{array}{c}\text { Overtime } \\
\text { wages }\end{array}$ & $\begin{array}{c}\text { Overtime } \\
\text { hours }\end{array}$ \\
\hline Food \& Kindred Products & 0.019 & 0.017 & 0.033 & $-0.151 *$ & $-0.160 *$ \\
\hline Tobacco Products & $0.105^{*}$ & -0.052 & $-0.096 * *$ & $0.278 *$ & 0.271 \\
\hline Textile Mill Products & 0.013 & 0.023 & 0.039 & $-0.143 *$ & $-0.147 *$ \\
\hline Apparel \& Other Textile Products & $0.020^{*}$ & 0.012 & 0.027 & $-0.141 *$ & $-0.154 *$ \\
\hline Lumber \& Wood Products & $0.049 *$ & 0.020 & 0.052 & $-0.312 *$ & $-0.345^{*}$ \\
\hline Furniture \& Fixtures & -0.011 & 0.019 & 0.021 & -0.011 & 0.004 \\
\hline Paper \& Allied Products & 0.022 & 0.025 & 0.045 & -0.044 & $-0.204 *$ \\
\hline Printing \& Publishing & -0.006 & 0.017 & 0.039 & $-0.193 *$ & -0.109 \\
\hline Chemical \& Allied Products & $0.097 *$ & -0.037 & $-0.061 *$ & -0.153 & 0.174 \\
\hline Petroleum \& Coal Products & -0.022 & 0.025 & 0.023 & 0.143 & 0.053 \\
\hline Rubber \& Misc. Plastic Products & $0.026^{*}$ & 0.002 & 0.012 & 0.027 & -0.032 \\
\hline Leather \& Leather Products & $-.022 * *$ & 0.054 & $0.064 *$ & -0.077 & -0.035 \\
\hline Stone, Clay, and Glass Products & 0.018 & 0.005 & 0.016 & -0.071 & -0.044 \\
\hline Primary Metal Industries & 0.003 & 0.034 & $0.049 *$ & -0.086 & -0.122 \\
\hline Fabricated Metal Products & 0.008 & 0.031 & 0.046 & $-0.131 * *$ & $-0.140 * *$ \\
\hline Industrial Machinery \& Equipment & $0.180 *$ & -0.072 & $-0.123 *$ & $-0.144 *$ & 0.348 \\
\hline Electronic \& Other Electric Equip. & $0.096 *$ & -0.022 & -0.026 & 0.303 & 0.076 \\
\hline Transportation Equipment & $0.078 *$ & 0.055 & $0.115^{*}$ & 0.000 & $-0.617 *$ \\
\hline Instruments \& Related Products & $0.140^{*}$ & -0.060 & $-0.103 *$ & $-0.572 *$ & $0.291 * *$ \\
\hline Misc. Manufacturing & $0.057 *$ & -0.004 & 0.016 & 0.266 & -0.041 \\
\hline Average Industry Elasticity 1972-95 & 0.048 & 0.005 & 0.009 & -0.128 & -0.046 \\
\hline Average Industry Elasticity: 1975 & 0.055 & -0.002 & -0.001 & -0.043 & -0.039 \\
\hline 1980 & 0.070 & -0.004 & -0.003 & -0.050 & -0.048 \\
\hline 1985 & 0.019 & 0.012 & 0.016 & -0.044 & -0.011 \\
\hline 1990 & 0.060 & 0.008 & 0.017 & -0.102 & -0.080 \\
\hline 1995 & 0.071 & 0.009 & 0.020 & -0.126 & -0.101 \\
\hline
\end{tabular}


These average elasticities of response have changed considerably over time. Average employment elasticities consistently increased during the sample period, and have changed from initial negative values during the 1970s to increasingly larger positive values. The tendency has been for average wage elasticities to increase over time, except for a short period in the middle of the 1980s. Average overtime wage and employment elasticities have remained consistently negative through out the sample period, with a slight absolute value increase.

The relative size of exchange rate effects on industry activity appears to be highly correlated with industry-specific characteristics other than its external orientation. In Table 4 we report the results of correlating the estimated elasticities reported in Table 3 with four different industry characteristics: average industry markup during the sample period, unionization rates, percent of workers without a college degree, and industry capital-labor ratios.

A clear pattern of correlation exists between our estimated exchange rate wage and employment elasticities and two variables: industry markups and the level of workers' education. Industries with higher price-over-cost markups also have higher wage (actual and overtime) responsiveness to exchange rates, but lower employment responsiveness (in terms of both hours and jobs). Industries with a higher share of unskilled workers also had relatively smaller wage elasticities but larger employment elasticities. This strong correlation between these specific industry characteristics and exchange rate elasticities suggest that issues such as the degree of education of the labor force, type of education and competitive pressures in the industry might result in quite different mechanisms for the adjustment of labor markets. We do not find a clear relationship between employment and wage responses to exchange rates in an industry and the industry's capital-labor ratios or unionization rates. 
Table 4 Weighted-Least-Square Regression Coefficients of Estimated Industry Elasticities against Industry Features

\begin{tabular}{|c|c|c|c|c|}
\hline $\begin{array}{l}\text { Elasticities of response } \\
\text { of changes in: }\end{array}$ & $\begin{array}{l}\text { Price-Over- } \\
\text { Cost Markup }\end{array}$ & $\begin{array}{l}\% \text { Non-College } \\
\text { Degree Workers }\end{array}$ & $\begin{array}{l}\text { Unionization } \\
\text { Rates }\end{array}$ & $\begin{array}{l}\text { Capital } \\
\text { Intensity }\end{array}$ \\
\hline Wages & $\begin{array}{l}0.221 * * \\
(1.867)\end{array}$ & $\begin{array}{l}-0.002 * * \\
(-1.764)\end{array}$ & $\begin{array}{l}-0.0003 \\
(-0.375)\end{array}$ & $\begin{array}{c}0.013 \\
(0.019)\end{array}$ \\
\hline Overtime wages & $\begin{array}{l}0.258 * \\
(3.096)\end{array}$ & $\begin{array}{l}-0.001 * \\
(-0.733)\end{array}$ & $\begin{array}{l}-0.001 \\
(-1.087)\end{array}$ & $\begin{array}{c}0.012 \\
(0.016)\end{array}$ \\
\hline Number of jobs & $\begin{array}{l}-0.384 * \\
(-3.251)\end{array}$ & $\begin{array}{l}0.003^{*} \\
(2.498)\end{array}$ & $\begin{array}{c}0.001 \\
(1.225)\end{array}$ & $\begin{array}{l}-0.032 * * \\
(-1.786)\end{array}$ \\
\hline Total hours & $\begin{array}{l}-0.175^{*} \\
(-2.452)\end{array}$ & $\begin{array}{l}0.001^{*} \\
(2.109)\end{array}$ & $\begin{array}{c}0.001 \\
(0.001)\end{array}$ & $\begin{array}{l}-0.009 \\
(0.012)\end{array}$ \\
\hline Overtime employment & $\begin{array}{l}0.163 * \\
(2.571)\end{array}$ & $\begin{array}{l}-0.001 * * \\
(-1.796)\end{array}$ & $\begin{array}{l}-0.001 \\
(-0.892)\end{array}$ & $\begin{array}{c}0.008 \\
(0.010)\end{array}$ \\
\hline
\end{tabular}

Notes: Weights are the inverse of the estimated standard errors from the elasticities. Industry responses use industry average external orientation ratios over 1972-1995.

* indicates significance at 5 percent level. Regression t-statistic in parentheses.

In the second mode of exploring this data, we explore cross-industry differences in their adjustment to exchange rate movements by re-estimating equation (13) separately for each industry. We computed for each of the 20 two-digit SIC manufacturing industries similar specifications to those that we have reported. However, because of the limited number of observations and degrees of freedom in each of these regressions, the regressions and estimates have very little power. The parameter estimates are extremely noisy and should be viewed with a great deal of skepticism. For completeness, we present the parameter estimates on exchange rate 
terms from these industry-specific regressions (Appendix Tables 2 and 3), but we do not have much faith in them. In the vast majority of cases, the hypothesis of an insignificant exchange rate effect could not be rejected for regressions on changes on regular wages and employment. However, there is a strong correlation between the estimated response elasticities for industry wages, overtime wages, and overtime employment reported in Table 4 and those implied from the industry specific regressions. However, the two approaches give nearly uncorrelated results for the two employment measures.

We also estimated all of our results using the industry-specific exchange rates computed using a weighted average of industry exports and imports with the 19 largest partner countries. The results from this estimation confirmed the results reported here. The F-test consistently rejected the null hypothesis of no exchange rate effects on wages and employment and estimated average wage and employment elasticities were small, and significantly correlated with the average industry markup and the proportion of skilled workers in the industry. The correlation between the average elasticities estimated using the two different measures of exchange rates were always positive and very high.

Further robustness checks on our findings were performed using 4-digit industry-level data on labor market outcomes. As more disaggregated series, these data can potentially provide more information into the type of adjustments spelled out in the theoretical section. The main disadvantage of these data is that using the 4-digit series limits the thoroughness of the potential analysis. First, the labor market data are not as complete. Employment is the total number of hours for production workers only. The NBER Productivity Database also does not contain data on overtime employment or jobs at the 4-digit level. Another disadvantage is that we cannot compute the appropriate imported input shares, since the input-output classification does not have a one-to-one correspondence with the 4-digit SIC classification. In the regressions, we proxied for imported-input shares using three different alternatives: the 4-digit import-to-consumption ratios; the 2-digit imported-input ratios; and by instrumenting the 2-digit SIC data with the 4-digit import-to-consumption ratios in constructing new imported-input shares.

These regressions using 4-digit industry data support the conclusions presented in the context of the 2-digit industry case. F-test results always reject the null hypothesis of exchange rate terms being jointly insignificant. Employment and jobs expand (contract) with dollar depreciations (appreciations). In these regressions, the signs and significance patterns of the wage 
effects are more mixed. As expected estimated 4-digit industry elasticities, constructed using parameter estimates from the alternative methodologies previously described, are always positively correlated with those from the 2 -digit regressions. The estimated wage elasticities are more positively correlated than the employment correlations, which capture also different components of the workforce.

\section{SUMMARY AND CONCLUDING REMARKS}

In this paper we have examined the effects of exchange rate movements on employment and wages for manufacturing industries in the United States. In theory, exchange rate movements affect the marginal revenue product of labor, and as a result, alter industry labor demand to the extent that these exchange rate movements affect the marginal profitability of firms in an industry. These movements in the marginal revenue product of labor will depend on the form of external exposure of each particular industry. The effects of an exchange rate movement will be sensitive to the export orientation of the industry, the amount of import competition, and the reliance on imported inputs into production of the industry. Other industry characteristics such as an industry's competitive structure, the composition of its labor force, and the characteristics of the production process will also determine the expected size of labor adjustment to an exchange rate shock.

We empirically estimated the effects of exchange rate changes on four different measures of labor market activity: wages and employment, and overtime employment and wages. The results indicate that labor market adjustments to exchange rate movements tend to be small but statistically significant. We find an average wage elasticity to exchange rates of 0.04 over 1972 to 1995, which is in line with other estimates from import competition studies (Revenga 1992, Slaughter and Swagel 1998). We also find that the importance of exchange rates for wages has been growing over time. This reflects the more rapid growth of export markets compared with the growth of imported input use in production. Our estimates of employment elasticities are significantly lower ( 0.01 on average). This low employment elasticities are consistent with larger 
elasticities at a more disaggregated industry level and a large amount of employment reallocation within a 2-digit industry (Davis and Haltiwanger 1997).

Industry-specific elasticities of response to exchange rate movements are significantly correlated with the skill composition of workers in an industry and the competitive structure of the industry. Industries with a higher proportion of college-educated workers observe higher wage elasticities and lower employment elasticities of response to exchange rates, despite the fact that the skill-intensive industries tend to be more export oriented. The reason may be that skill intensive industries have relatively higher costs of hiring or firing workers. We also find that high price-over-cost markup industries and more skill-intensive industries, also have relatively larger overtime wage and employment responses to exchange rates. On the margin, more skill intensive industries use overtime activity rather than hiring and firing workers, or changing basic compensation. We find other indicators of industry characteristics -- unionization rates, and capital intensities -- to be uncorrelated with the size of industry response to exchange rates. 


\section{REFERENCES}

Allayannis, G. and X. Ihrig. 1998. "Exchange Rate Exposure and Industry Structure" University of Virginia working paper.

Bodnar, G., B. Dumas and R. Marston. 1998. "Pass-through and Exposure" Wharton School working paper.

Bernard, A. and B. Jensen. 1995. Exporters, Jobs, and Wages in U.S. Manufacturing: 1976-1987" Brookings Papers on Economic Activity on Microeconomics pp.67- 117.

Beveridge, S. and Nelson, C. 1981. "A New Approach to the Decomposition of Economic Time Series Into Permanent and Transitory Components," Journal of Monetary Economics, 33, No.1, pp. 5-38.

Branson, W., and J. Love. 1988. "United States Manufacturing and the Real Exchange Rate.” In R. Marston, ed., Misalignment of Exchange Rates: Effects on Trade and Industry, University of Chicago Press.

Branson, W., and R. Marston. 1989. "Price and Output Adjustment in Japanese Manufacturing." National Bureau of Economic Research Working Paper no. 2878.

Brunello, G. 1990. "Real Exchange Rate Variability and Japanese Industrial Employment," Journal of the Japanese and International Economies.

Burgess, S. and M. Knetter 1996. An International Comparison of Employment Adjustment to Exchange Rate Fluctuations. NBER working paper 5861 (December).

Campa, J., and L. Goldberg. 1995. "Investment, Exchange Rates and External Exposure." Journal of International Economics 38 (May): 297-320.

Campa, J., and L. Goldberg. 1996a. "Investment, Pass-Through and Exchange Rates: A CrossCountry Comparison." forthcoming International Economic Review.

Campa, J., and L. Goldberg. 1997. "The Evolving External Orientation of Manufacturing: Evidence from Four Countries.” Economic Policy Review (July 1997, Federal Reserve Bank of New York). See also NBER working paper 5919 (February).

Campbell, J. and Clarida, R. 1987. "The Dollar and Real Interest Rates: An Empirical Investigation," Carnegie-Rochester Conference Series on Public Policy, 27, pp. 103-140.

Clarida, R. and Gali, J. 1994. "Sources of real exchange rate fluctuations: How important are nominal shocks?," Carnegie-Rochester Conference Series on Public Policy, 41, pp. 1-56. 
Davis, S. and J. Haltiwanger. 1997. "Sectoral Job Creation and Destruction Responses to Oil Price Changes and Other Shocks.” Manuscript, University of Chicago.

Domowitz, I., G. Hubbard, and B. Petersen. 1986. "Business Cycles and the Relationship between Concentration and Price-Cost Margins." Rand Journal of Economics 17 (Spring): $1-17$.

Dornbusch, R. 1987. "Exchange Rates and Prices.” American Economic Review 77 (March): 93106.

Freeman, R. and L. Katz. 1991. "Industrial Wage and Employment Determination in an Open Economy". in J. Abowd and R. Freeman eds. Immigration, Trade, and the Labor Market (Chicago: University of Chicago Press).

Goldberg, L. 1993. "Exchange Rates and Investment in United States Industry." Review of Economics and Statistics LXXV, no. 4 (November): 575-88.

Goldberg, L. and J. Tracy. 1999. "Exchange Rates and Local Labor Markets" in R. Feenstra ed. The Impact of International Trade on Wages. NBER and University of Chicago Press, forthcoming.

Hall, R. 1988. "The Relation Between Price and Marginal Cost in U.S. Industry." Journal of Political Economy 96 (October): 921-47.

Huizinga, J. 1987. "An Empirical Investigation of the Long Run Behavior of Real Exchange Rates," Carnegie-Rochester Conference Series on Public Policy, 27, pp. 149-215.

Kletzer, L. 1998. "Trade and Job Loss in U.S. Manufacturing”. Manuscript. U.C. Santa Cruz..

Knetter, M., 1989. "Price Discrimination by U.S. and German Exporters." American Economic Review 79 (March): 198-210.

Marston, R. 1990. "Pricing to Market in Japanese Manufacturing." Journal of International Economics 29 (November): 217-36.

Nickell, S. 1986. Dynamic Models of Labour Demand. in Handbook of Labor Economics volume I edited by O. Ashenfelter and R. Layard pp.473-522.

Revenga, A. 1992. "Exporting Jobs? The Impact of Import Competition on Employment and Wages in the U.S. Manufacturing," Quarterly Journal of Economics 107 (1): pp.255-284.

Slaughter, M. and P. Swagel, 1998. "The Effect of Import Competition on Wages and Employment: Evidence from the Advanced Economies," mimeo, Dartmouth College. 


\section{Data Appendix}

All wages were deflated from nominal values to real values using the consumer price index from the IMF International Financial Statistics, line 4. The measures of export share, import to domestic consumption share, and imported input share are taken from Campa and Goldberg (1997). The exchange rate is the real effective exchange rate index, defined as dollars per unit of foreign currency, from the IMF International Financial Statistics, line reu. Prior to 1975 the real exchange rate index was computed by deflating the bilateral nominal exchange rates with the countries wholesale price index and computing the index using the IMF weights. The interest rate is the long-term interest rate from the IMF International Financial Statistics, line 61. Oil Price is the real domestic currency price of average price of crude oil IMF International Financial Statistics. Real Gross Domestic Product in 1990 prices is from IMF International Financial Statistics, line 99b.

Computation of Permanent Exchange Rates: As derived in the previous section investment responds to permanent changes in exchange rates. Therefore, we need to decompose the real exchange rates into their permanent and transitory components. We computed the permanent exchange rate series using the decomposition first suggested by Beveridge and Nelson (1981) and later employed to exchange rate data by Huizinga (1987), Campbell and Clarida (1987), Cumby and Huizinga (1990), and Clarida and Gali (1994), among others.

The Beveridge-Nelson procedure consists of decomposing an I(1) time series into its transitory and permanent components. For the real exchange rate at time $\mathrm{t}, e_{t}$, this is expressed as $e_{t}=e_{t}^{B N}+\hat{e}_{t}^{B N}$, where the permanent component is denoted by “^". The transitory departure of the real exchange rate from its expected long-run equilibrium, $e_{t}^{B N}$, is given by:

$$
e_{t}^{B N}=-E_{t}\left(\sum_{j=1}^{\infty} \Delta e_{t+j} \mid \Delta e_{t}, \Delta e_{t-1}, \ldots\right)
$$

with the permanent component defined by:

$$
\hat{e}_{t}^{B N}=e_{t}+E_{t}\left(\sum_{j=1}^{\infty} \Delta e_{t+j} \mid \Delta e_{t}, \Delta e_{t-1}, \ldots\right)
$$

Beveridge and Nelson (1981) proved that the first of these components is a stationary process, while the second is a random walk. 
We follow Beveridge and Nelson (1981) and Huizinga (1987) and model the exchange rate decomposition using lags of the real exchange rate. ${ }^{20}$ In particular, we assume that the first differences of the quarterly (log) real exchange rate follow an $\mathrm{AR}(4)$ process, so that:

$E_{t}\left(e_{t}^{B N}\right)=-E_{t}\left(\sum_{j=1}^{\infty} \Delta e_{t+j} \mid \Delta e_{t}, \Delta e_{t-1}, \Delta e_{t-2}, \Delta e_{t-3}\right)$

The actual variance decomposition results suggest that the temporary component of exchange rate changes accounts for only a small proportion of the variance of the real exchange rate series. ${ }^{21}$ The variance of the transitory component of the real exchange rate accounts for about 40 percent of the total variability of the real exchange rates.

20 We also tried a multivariate system in which we also included three lags of the country's quarterly inflation rate and GDP growth. The results of the decomposition were very similar, with an average correlation between the permanent components about 0.9. Given that these exchange rates are trade-weighted multilateral indices, we decided to report and utilize only the univariate decompositions.

21 Similar results are reported in Clarida and Galí (1994). 
Appendix Table A1: Relative Variability of Annual Wage, Employment and Overtime Series

\begin{tabular}{|l||c|c|}
\hline \multicolumn{1}{|c||}{} & \multicolumn{2}{c|}{$\begin{array}{c}\text { Average Coefficients of Variation } \\
\text { (minimum coefficient variation, maximum coefficient variation) }\end{array}$} \\
\hline Wages & Across Industries & Within Industries \\
\hline Number of jobs & 0.242 & 0.066 \\
& $(0.193,0.289)$ & $(0.022,0.274)$ \\
\hline Total hours & 0.044 & 0.053 \\
& $(0.022,0.070)$ & $(0.023,0.091)$ \\
\hline overtime wages & 0.051 & $(0.034,0.132)$ \\
& $(0.025,0.081)$ & 0.158 \\
& 0.407 & $(0.054,0.491)$ \\
\hline overtime employment & $(0.330,0469)$ & 0.178 \\
& $(0.268,0.362)$ & $(0.078,0.388)$ \\
\hline
\end{tabular}

\begin{tabular}{|l||c|c|c|c|}
\hline \multicolumn{1}{|c||}{} & \multicolumn{4}{c|}{$\begin{array}{r}\text { Ratio of within industry Coefficients of Variability } \\
\text { for Industries sorted relative to median characteristic }\end{array}$} \\
\cline { 1 - 5 } & $\begin{array}{c}\text { High / Low } \\
\text { Price-Over- } \\
\text { Cost Markup }\end{array}$ & $\begin{array}{c}\text { High/Low } \\
\text { \% Non-College } \\
\text { Degree Workers }\end{array}$ & $\begin{array}{c}\text { High / Low } \\
\text { Unionization } \\
\text { Rates }\end{array}$ & $\begin{array}{c}\text { High / Low } \\
\text { Capital Intensity }\end{array}$ \\
\hline Wages & 0.950 & 1.041 & 1.045 & 1.095 \\
\hline number of jobs & 0.929 & 0.989 & 0.924 & 0.796 \\
\hline total hours & 0.901 & 0.910 & 1.156 & 0.9 \\
\hline overtime wages & 1.068 & 0.746 & 1.160 & 1.240 \\
\hline overtime employment & 0.926 & 0.895 & 1.109 & 1.147 \\
\hline
\end{tabular}


Table A2 Permanent Exchange Rate Movements and Industry-Specific Wage and Employment Ri This table reports the estimated coefficients and t-statistics (in parentheses) of industry-specific regressions. $\mathrm{T}$ two different specifications of equation (13): including only the exchange rate, and including the exchange rat share, $\mathrm{X}_{\mathrm{it}}$, and with the imported input share, $\forall_{\mathrm{it}}$, of the industry. The increase in adjusted $\mathrm{R}^{2}$ relative to an specifi rate term is also reported.

\begin{tabular}{|c|c|c|c|c|c|c|c|c|c|c|}
\hline \multicolumn{3}{|c|}{ Industry } & \multicolumn{3}{|c|}{ Wage Response } & \multicolumn{4}{|c|}{ Employment Response } & \multirow[b]{2}{*}{$\Delta \mathrm{R}^{\prime}$} \\
\hline & $\Delta \mathrm{ER}_{\mathrm{t}}$ & $\Delta \mathrm{R}^{2}$ & $\mathrm{X}_{\mathrm{it}-1} \Delta \mathrm{ER}_{\mathrm{t}}$ & $\forall_{\mathrm{it}-1} \Delta \mathrm{ER}_{\mathrm{t}}$ & $\Delta \mathrm{R}^{2}$ & $\Delta \mathrm{ER}_{\mathrm{t}}$ & $\Delta \mathrm{R}^{2}$ & $\mathrm{X}_{\mathrm{it}-1} \Delta \mathrm{ER}_{\mathrm{t}}$ & $\forall_{\mathrm{I}, \mathrm{t}-1} \Delta \mathrm{ER}_{\mathrm{t}}$ & \\
\hline 20 & $\begin{array}{l}0.07 * * \\
(0.04)\end{array}$ & 0.14 & $\begin{array}{c}1.733 \\
(6.373) \\
\end{array}$ & $\begin{array}{l}0.008 \\
(7.369) \\
\end{array}$ & 0.11 & $\begin{array}{l}0.03 \\
(0.03) \\
\end{array}$ & 0.00 & $\begin{array}{l}6.708 \\
(5.000) \\
\end{array}$ & $\begin{array}{l}-7.090 \\
(5.989) \\
\end{array}$ & 0.0 \\
\hline 21 & $\begin{array}{l}-0.04 \\
(0.11)\end{array}$ & -0.07 & $\begin{array}{l}-16.285^{*} \\
(6.867)\end{array}$ & $\begin{array}{l}83.275^{*} \\
(36.466)\end{array}$ & 0.16 & $\begin{array}{l}0.05 \\
(0.08)\end{array}$ & -0.02 & $\begin{array}{l}9.434^{*} \\
(4.981)\end{array}$ & $\begin{array}{l}-47.291 * * \\
(26.509)\end{array}$ & 0.0 \\
\hline 22 & $\begin{array}{l}-0.04 \\
(0.05)\end{array}$ & -0.03 & $\begin{array}{l}-3.268 \\
(3.945)\end{array}$ & $\begin{array}{l}2.036 \\
(3.524)\end{array}$ & -0.06 & $\begin{array}{l}0.22^{*} \\
(0.11)\end{array}$ & 0.10 & $\begin{array}{l}-13.207 * * \\
(7.186)\end{array}$ & $\begin{array}{l}16.636^{*} \\
(6.427)\end{array}$ & 0.2 \\
\hline 23 & $\begin{array}{c}0.02 \\
(0.05) \\
\end{array}$ & -0.04 & $\begin{array}{l}4.580 \\
(6.057) \\
\end{array}$ & $\begin{array}{l}-4.256 \\
(7.060) \\
\end{array}$ & -0.04 & $\begin{array}{l}0.00 \\
(0.10)\end{array}$ & -0.04 & $\begin{array}{l}-2.791 \\
(12.598) \\
\end{array}$ & $\begin{array}{l}4.131 \\
(14.817)\end{array}$ & $-0 .($ \\
\hline 24 & $\begin{array}{c}0.18^{*} \\
(0.06) \\
\end{array}$ & 0.35 & $\begin{array}{l}4.576 \\
(3.976) \\
\end{array}$ & $\begin{array}{l}-3.099 \\
(7.583) \\
\end{array}$ & 0.35 & $\begin{array}{l}-0.06 \\
(0.12)\end{array}$ & -0.01 & $\begin{array}{l}-10.956 \\
(8.410) \\
\end{array}$ & $\begin{array}{c}19.039 \\
(16.036) \\
\end{array}$ & $-0 .($ \\
\hline 25 & $\begin{array}{c}0.05 \\
(0.04) \\
\end{array}$ & 0.04 & $\begin{array}{l}-1.017 \\
(7.164) \\
\end{array}$ & $\begin{array}{l}1.482 \\
(2.651)\end{array}$ & -0.02 & $\begin{array}{l}-0.04 \\
(0.08)\end{array}$ & -0.01 & $\begin{array}{l}-17.652 \\
(12.462) \\
\end{array}$ & $\begin{array}{c}5.529 \\
(4.589) \\
\end{array}$ & 0.0 \\
\hline 26 & $\begin{array}{l}-0.01 \\
(0.04) \\
\end{array}$ & -0.02 & $\begin{array}{l}-0.836 \\
(4.458) \\
\end{array}$ & $\begin{array}{c}0.783 \\
(4.489) \\
\end{array}$ & -0.05 & $\begin{array}{l}-0.01 \\
(0.05)\end{array}$ & -0.03 & $\begin{array}{l}-5.697 \\
(6.220) \\
\end{array}$ & $\begin{array}{l}5.644 \\
(6.306) \\
\end{array}$ & $-0 .($ \\
\hline 27 & $\begin{array}{c}0.02 \\
(0.04)\end{array}$ & -0.01 & $\begin{array}{l}-18.700 * * \\
(10.617)\end{array}$ & $\begin{array}{c}9.615 \\
(5.065) \\
\end{array}$ & 0.09 & $\begin{array}{l}0.02 \\
(0.01)\end{array}$ & -0.01 & $\begin{array}{l}-35.647^{*} \\
(14.317)\end{array}$ & $\begin{array}{l}16.870^{*} \\
(6.824) \\
\end{array}$ & 0.0 \\
\hline 28 & $\begin{array}{l}-0.05 \\
(0.07)\end{array}$ & -0.02 & $\begin{array}{l}-1.259 \\
(3.952)\end{array}$ & $\begin{array}{c}2.317 \\
(10.622)\end{array}$ & -0.07 & $\begin{array}{l}-0.01 \\
(0.07)\end{array}$ & -0.03 & $\begin{array}{l}-4.091 \\
(4.667)\end{array}$ & $\begin{array}{l}10.906 \\
(12.683)\end{array}$ & $-0 .($ \\
\hline 29 & $\begin{array}{l}-0.26^{*} \\
(0.10)\end{array}$ & 0.30 & $\begin{array}{l}-13.388 \\
(25.574)\end{array}$ & $\begin{array}{c}2.016 \\
(11.748)\end{array}$ & 0.30 & $\begin{array}{l}-0.10 \\
(0.10)\end{array}$ & 0.00 & $\begin{array}{l}-2.928 \\
(28.432)\end{array}$ & $\begin{array}{l}-0.053 \\
(13.070)\end{array}$ & -0.0 \\
\hline 30 & $\begin{array}{c}0.07 \\
(0.04)\end{array}$ & 0.13 & $\begin{array}{l}-10.841^{*} \\
(4.410)\end{array}$ & $\begin{array}{l}14.531 * * \\
(5.209)\end{array}$ & 0.23 & $\begin{array}{l}-0.07 \\
(0.09)\end{array}$ & -0.00 & $\begin{array}{l}-12.036 \\
(9.821)\end{array}$ & $\begin{array}{c}12.701 \\
(11.762)\end{array}$ & 0.0 \\
\hline
\end{tabular}

* Significant at 5 percent. ** significant at 10 percent. 
Table A2 (cont'd) Permanent Exchange Rate Movements and Industry-Specific Wage and Employme

\begin{tabular}{|c|c|c|c|c|c|c|c|c|c|c|}
\hline \multicolumn{3}{|c|}{ Industry } & \multicolumn{5}{|c|}{ Wage Response } & \multicolumn{3}{|c|}{ Employment Response } \\
\hline & 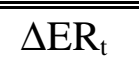 & 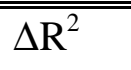 & $\overline{\mathrm{X}_{\mathrm{it}-1} \Delta \mathrm{ER}_{\mathrm{t}}}$ & $\forall_{\text {it }-1} \Delta \mathrm{ER}_{\mathrm{t}}$ & 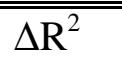 & 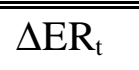 & 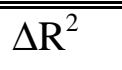 & $\mathrm{X}_{\mathrm{it}-1} \Delta \mathrm{ER}_{\mathrm{t}}$ & $\forall_{\mathrm{I}, \mathrm{t}-1} \Delta \mathrm{ER}_{\mathrm{t}}$ & $\overline{\overline{\Delta \mathrm{R}^{\prime}}}$ \\
\hline 31 & $\begin{array}{l}-0.01 \\
(0.04)\end{array}$ & -0.04 & $\begin{array}{l}-0.607 \\
(3.341)\end{array}$ & $\begin{array}{l}0.351 \\
(1.457)\end{array}$ & -0.07 & $\begin{array}{l}-0.17 \\
(0.11)\end{array}$ & 0.10 & $\begin{array}{l}-8.628 \\
(9.049)\end{array}$ & $\begin{array}{l}2.727 \\
(3.899)\end{array}$ & $0 . \mathrm{C}$ \\
\hline 32 & $\begin{array}{l}-0.02 \\
(0.05)\end{array}$ & -0.04 & $\begin{array}{l}12.568^{*} \\
(3.956)\end{array}$ & $\begin{array}{l}-14.724^{*} \\
(4.255)\end{array}$ & 0.20 & $\begin{array}{l}0.03 \\
(0.06)\end{array}$ & -0.00 & $\begin{array}{l}2.489 \\
(6.442)\end{array}$ & $\begin{array}{l}-1.955 \\
(6.960)\end{array}$ & $-0 . c$ \\
\hline 33 & $\begin{array}{l}-0.08 \\
(0.08)\end{array}$ & 0.00 & $\begin{array}{c}2.171 \\
(4.950)\end{array}$ & $\begin{array}{l}-2.089 \\
(2.498)\end{array}$ & -0.02 & $\begin{array}{l}0.21 * * \\
(0.12)\end{array}$ & 0.02 & $\begin{array}{l}10.425 \\
(7.302)\end{array}$ & $\begin{array}{l}-3.176 \\
(3.572)\end{array}$ & $0 . C$ \\
\hline 34 & $\begin{array}{l}-0.02 \\
(0.18)\end{array}$ & -0.06 & $\begin{array}{l}5.680 \\
(13.702)\end{array}$ & $\begin{array}{l}-3.949 \\
(9.222)\end{array}$ & -0.11 & $\begin{array}{l}-0.06 \\
(0.05)\end{array}$ & 0.01 & $\begin{array}{l}7.198 * * \\
(3.988)\end{array}$ & $\begin{array}{l}-5.489^{*} \\
(2.594)\end{array}$ & $0 . C$ \\
\hline 35 & $\begin{array}{c}0.21^{*} \\
(0.18)\end{array}$ & 0.26 & $\begin{array}{l}-2.235 \\
(2.904)\end{array}$ & $\begin{array}{c}8.791 \\
(7.675)\end{array}$ & 0.23 & $\begin{array}{l}-0.03 \\
(0.07)\end{array}$ & -0.01 & $\begin{array}{l}3.529 * * \\
(1.991)\end{array}$ & $\begin{array}{l}-9.791 * * \\
(5.262)\end{array}$ & $0 . \mathrm{C}$ \\
\hline$\underline{36}$ & $\begin{array}{l}-0.38 * \\
(0.10)\end{array}$ & 0.40 & $\begin{array}{l}12.713^{*} \\
(5.465) \\
\end{array}$ & $\begin{array}{l}-27.735^{*} \\
(9.478)\end{array}$ & 0.54 & $\begin{array}{l}-0.18^{*} \\
(0.09)\end{array}$ & 0.08 & $\begin{array}{l}-8.233 \\
(5.272) \\
\end{array}$ & $\begin{array}{l}11.618 \\
(9.234) \\
\end{array}$ & 0.1 \\
\hline 37 & $\begin{array}{l}0.24 \\
(0.16)\end{array}$ & 0.04 & $\begin{array}{c}3.224 \\
(4.878)\end{array}$ & $\begin{array}{l}-2.067 \\
(6.388)\end{array}$ & 0.01 & $\begin{array}{l}-0.03 \\
(0.05)\end{array}$ & -0.00 & $\begin{array}{l}-0.464 \\
(1.861)\end{array}$ & $\begin{array}{c}0.309 \\
(2.448)\end{array}$ & $-0 . c$ \\
\hline 38 & $\begin{array}{l}0.69^{*} \\
(0.18)\end{array}$ & 0.60 & $\begin{array}{l}-25.653^{*} \\
(4.360)\end{array}$ & $\begin{array}{c}92.874 * \\
(13.265)\end{array}$ & 0.46 & $\begin{array}{l}-0.02 \\
(0.09)\end{array}$ & -0.02 & $\begin{array}{l}-1.749 \\
(4.628)\end{array}$ & $\begin{array}{l}4.869 \\
(14.300)\end{array}$ & $-0 . c$ \\
\hline 39 & $\begin{array}{l}-0.01 \\
(0.05)\end{array}$ & -0.04 & $\begin{array}{l}-1.790 \\
(1.782)\end{array}$ & $\begin{array}{l}1.989 \\
(2.148)\end{array}$ & -0.03 & $\begin{array}{l}0.09 \\
(0.07)\end{array}$ & 0.01 & $\begin{array}{c}0.364 \\
(2.874)\end{array}$ & $\begin{array}{l}0.652 \\
(3.475)\end{array}$ & $-0 . c$ \\
\hline & $\begin{array}{l}\text { ificant ce } \\
6 / 20\end{array}$ & fficients & $6 / 20$ & $5 / 20$ & & $3 / 20$ & & $5 / 20$ & $4 / 20$ & \\
\hline & $9 / 11$ & & $8 / 12$ & $13 / 7$ & & $8 / 12$ & & $7 / 13$ & $13 / 7$ & \\
\hline
\end{tabular}

\footnotetext{
* significant at 5 percent. ** significant at 10 percent.
} 
Table A3 Actual exchange rate effects on industry overtime employment and overtime wages

This table reports the estimated coefficients and t-statistics (in parentheses) of industry-specific regressions. T] two different specifications of equation (13), without the lagged employment variable: including only the exch exchange rate interacted with the export share, $X_{\text {it }}$, and with the imported input share, $\forall_{\text {it }}$, of the industry. The in to an specification without any exchange rate term is also reported.

\begin{tabular}{|c|c|c|c|c|c|c|c|c|c|c|}
\hline \multicolumn{2}{|c|}{ Industry } & \multicolumn{4}{|c|}{ Overtime Wage Response } & \multicolumn{5}{|c|}{ Overtime Employment Response } \\
\hline & 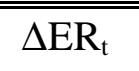 & 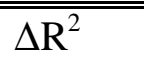 & $\overline{\mathrm{X}_{\mathrm{it}-1} \Delta \mathrm{ER}_{\mathrm{t}}}$ & $\forall_{\mathrm{it}-1} \Delta \mathrm{ER}_{\mathrm{t}}$ & 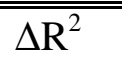 & 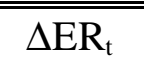 & 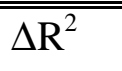 & $\overline{\mathrm{X}_{\mathrm{it}-1} \Delta \mathrm{ER}_{\mathrm{t}}}$ & $\forall_{\mathrm{I}, \mathrm{t}-1} \Delta \mathrm{ER}_{\mathrm{t}}$ & $\overline{\overline{\Delta \Delta \mathrm{R}^{\prime}}}$ \\
\hline 20 & $\begin{array}{c}0.01 \\
(0.07)\end{array}$ & -0.03 & $\begin{array}{l}-2.162 \\
(10.456)\end{array}$ & $\begin{array}{l}2.937 \\
(12.640)\end{array}$ & $\begin{array}{l}0.03 \\
-0.07\end{array}$ & $\begin{array}{l}0.01 \\
(0.08)\end{array}$ & -0.03 & $\begin{array}{l}-11.558 \\
(10.770)\end{array}$ & $\begin{array}{l}14.211 \\
(13.017)\end{array}$ & $\begin{array}{l}0.5 ! \\
-0.1\end{array}$ \\
\hline 21 & $\begin{array}{c}1.87^{*} \\
(0.67)\end{array}$ & 0.21 & $\begin{array}{l}-33.800 \\
(39.096)\end{array}$ & $\begin{array}{l}285.57 \\
(213.12)\end{array}$ & $\begin{array}{l}3.64 \\
0.20\end{array}$ & $\begin{array}{l}1.92^{*} \\
(0.65)\end{array}$ & 0.24 & $\begin{array}{l}-30.944 \\
(38.310)\end{array}$ & $\begin{array}{l}272.91 \\
(208.34)\end{array}$ & $\begin{array}{l}3.91 \\
0.2\end{array}$ \\
\hline 22 & $\begin{array}{c}0.11 \\
(0.23)\end{array}$ & -0.02 & $\begin{array}{l}11.887 \\
(16.934)\end{array}$ & $\begin{array}{l}-7.426 \\
(14.528)\end{array}$ & $\begin{array}{l}0.33 \\
-0.02\end{array}$ & $\begin{array}{l}0.20 \\
(0.28)\end{array}$ & -0.02 & $\begin{array}{l}13.184 \\
(21.062)\end{array}$ & $\begin{array}{l}-6.618 \\
(18.105)\end{array}$ & $\begin{array}{l}0.4 \\
-0.1\end{array}$ \\
\hline 23 & $\begin{array}{c}0.04 \\
(0.15)\end{array}$ & -0.01 & $\begin{array}{l}0.478 \\
(16.986)\end{array}$ & $\begin{array}{l}2.030 \\
(20.364)\end{array}$ & $\begin{array}{l}0.06 \\
-0.03\end{array}$ & $\begin{array}{c}0.02 \\
(0.19)\end{array}$ & -0.02 & $\begin{array}{l}-12.739 \\
(21.859)\end{array}$ & $\begin{array}{l}16.778 \\
(26.272)\end{array}$ & $\begin{array}{l}0.1 ! \\
-0.1\end{array}$ \\
\hline 24 & $\begin{array}{l}-0.17 \\
(0.22) \\
\end{array}$ & 0.01 & $\begin{array}{l}4.224 \\
(14.084) \\
\end{array}$ & $\begin{array}{l}-13.316 \\
(27.095) \\
\end{array}$ & $\begin{array}{l}0.23 \\
-0.01 \\
\end{array}$ & $\begin{array}{l}-0.21 \\
(0.20)\end{array}$ & 0.03 & $\begin{array}{l}-0.781 \\
(14.559) \\
\end{array}$ & $\begin{array}{l}-4.650 \\
(27.555) \\
\end{array}$ & $\begin{array}{l}0.3^{\prime} \\
0.01\end{array}$ \\
\hline 25 & $\begin{array}{l}-0.28 \\
(0.29)\end{array}$ & 0.02 & $\begin{array}{l}-29.850 \\
(42.050)\end{array}$ & $\begin{array}{l}5.170 \\
(16.805)\end{array}$ & $\begin{array}{l}0.65 \\
0.01\end{array}$ & $\begin{array}{l}-0.40 \\
(0.31)\end{array}$ & 0.04 & $\begin{array}{l}-37.488 \\
(45.372)\end{array}$ & $\begin{array}{l}5.705 \\
(17.956)\end{array}$ & $\begin{array}{l}1.0 ! \\
0.0\end{array}$ \\
\hline 26 & $\begin{array}{l}-0.08 \\
(0.18)\end{array}$ & -0.03 & $\begin{array}{l}-11.878 \\
(19.569)\end{array}$ & $\begin{array}{l}11.641 \\
(20.492)\end{array}$ & $\begin{array}{l}0.15 \\
-0.07\end{array}$ & $\begin{array}{l}-0.07 \\
(0.19)\end{array}$ & -0.04 & $\begin{array}{l}-21.259 \\
(21.050)\end{array}$ & $\begin{array}{l}21.570 \\
(22.032)\end{array}$ & $\begin{array}{l}0.2 \text { : } \\
-0.1\end{array}$ \\
\hline 27 & $\begin{array}{l}-0.06 \\
(0.16)\end{array}$ & -0.01 & $\begin{array}{l}-76.710 \\
(51.703) \\
\end{array}$ & $\begin{array}{l}36.294 \\
(25.187) \\
\end{array}$ & $\begin{array}{l}0.93 \\
-0.02 \\
\end{array}$ & $\begin{array}{l}-0.06 \\
(0.15)\end{array}$ & -0.01 & $\begin{array}{l}-76.260 \\
(51.403) \\
\end{array}$ & $\begin{array}{l}35.611 \\
(24.979) \\
\end{array}$ & $\begin{array}{l}0.91 \\
-0.1 \\
\end{array}$ \\
\hline 28 & $\begin{array}{c}0.04 \\
(0.13)\end{array}$ & -0.02 & $\begin{array}{l}-10.404 \\
(7.667)\end{array}$ & $\begin{array}{l}30.803 \\
(21.897) \\
\end{array}$ & $\begin{array}{l}0.82 \\
-0.03 \\
\end{array}$ & $\begin{array}{l}0.11 \\
(0.14)\end{array}$ & -0.00 & $\begin{array}{r}-9.536 \\
(8.297) \\
\end{array}$ & $\begin{array}{l}29.7597 \\
(23.601)\end{array}$ & $\begin{array}{l}0.9 \text {. } \\
-0.1\end{array}$ \\
\hline 29 & $\begin{array}{l}-0.00 \\
(0.22) \\
\end{array}$ & -0.05 & $\begin{array}{c}28.594 \\
(44.551) \\
\end{array}$ & $\begin{array}{l}-11.843 \\
(19.667) \\
\end{array}$ & $\begin{array}{l}0.20 \\
-0.09 \\
\end{array}$ & $\begin{array}{l}0.10 \\
(0.25) \\
\end{array}$ & -0.04 & $\begin{array}{l}30.324 \\
(50.799) \\
\end{array}$ & $\begin{array}{l}-10.607 \\
(22.449) \\
\end{array}$ & $\begin{array}{l}0.3^{\prime} \\
-0.6 \\
\end{array}$ \\
\hline
\end{tabular}

* significant at 5 percent. ** significant at 10 percent. 
Table A3 (continued) Actual exchange rate effects on industry overtime employment and overtime w

\begin{tabular}{|c|c|c|c|c|c|c|c|c|c|c|}
\hline Ind & & Overtime & age $\mathrm{Re}$ & onse & & 3 & loys & Respo & & \\
\hline 30 & $\begin{array}{l}\Delta \mathrm{ER}_{\mathrm{t}} \\
-0.36 \\
(0.24)\end{array}$ & 0.06 & $\begin{array}{l}X_{\mathrm{it}-1} \Delta \mathrm{ER}_{\mathrm{t}} \\
-37.610 \\
(23.737)\end{array}$ & $\begin{array}{l}\forall_{\text {it- } 1} \Delta \mathrm{ER}_{\mathrm{t}} \\
37.733 \\
(29.204)\end{array}$ & $\begin{array}{l}\Delta \mathrm{R}^{2} \\
1.66 \\
0.04\end{array}$ & $\begin{array}{l}\Delta \mathrm{ER}_{\mathrm{t}} \\
-0.35 \\
(0.26)\end{array}$ & $\begin{array}{l}\Delta \mathrm{R}^{2} \\
0.04\end{array}$ & $\begin{array}{l}X_{\mathrm{it}-1} \Delta \mathrm{ER}_{\mathrm{t}} \\
-37.502 \\
(26.194)\end{array}$ & $\begin{array}{l}\forall_{\mathrm{I}, \mathrm{t}-1} \Delta \mathrm{ER}_{\mathrm{t}} \\
37.334 \\
(32.133)\end{array}$ & $\begin{array}{l}\Delta \mathrm{R}^{\prime} \\
1.3 ! \\
0.0\end{array}$ \\
\hline 31 & $\begin{array}{c}0.37 \\
(0.23)\end{array}$ & 0.08 & $\begin{array}{l}-16.977 \\
(17.780)\end{array}$ & $\begin{array}{l}10.309 \\
(7.921)\end{array}$ & $\begin{array}{l}1.90 \\
0.11\end{array}$ & $\begin{array}{c}0.40 \\
(0.26)\end{array}$ & 0.09 & $\begin{array}{l}-26.094 \\
(19.761)\end{array}$ & $\begin{array}{l}14.585 \\
(8.797)\end{array}$ & $\begin{array}{l}2.2: \\
0.11\end{array}$ \\
\hline 32 & $\begin{array}{l}-0.23 \\
(0.15)\end{array}$ & 0.01 & $\begin{array}{l}-22.865 \\
(15.233)\end{array}$ & $\begin{array}{l}19.646 \\
(17.223) \\
\end{array}$ & $\begin{array}{l}1.63 \\
0.02 \\
\end{array}$ & $\begin{array}{c}-0.27 * \\
(0.14)\end{array}$ & 0.03 & $\begin{array}{l}-21.073 \\
(14.833) \\
\end{array}$ & $\begin{array}{l}15.861 \\
(16.753)\end{array}$ & $\begin{array}{l}1.81 \\
0.0 \\
\end{array}$ \\
\hline 33 & $\begin{array}{l}-0.07 \\
(0.25) \\
\end{array}$ & -0.01 & $\begin{array}{l}-10.778 \\
(16.991) \\
\end{array}$ & $\begin{array}{l}5.165 \\
(9.369) \\
\end{array}$ & $\begin{array}{l}0.14 \\
-0.04 \\
\end{array}$ & $\begin{array}{l}-0.09 \\
(0.29) \\
\end{array}$ & -0.01 & $\begin{array}{l}-19.190 \\
(19.258) \\
\end{array}$ & $\begin{array}{l}9.643 \\
(10.659) \\
\end{array}$ & $\begin{array}{l}0.3 ! \\
-0.6 \\
\end{array}$ \\
\hline 34 & $\begin{array}{l}-0.31 \\
(0.25)\end{array}$ & 0.02 & $\begin{array}{l}-8.353 \\
(16.390)\end{array}$ & $\begin{array}{l}1.986 \\
(11.881)\end{array}$ & $\begin{array}{l}0.65 \\
0.00 \\
\end{array}$ & $\begin{array}{l}-0.31 \\
(0.26)\end{array}$ & 0.02 & $\begin{array}{c}-9.403 \\
(17.446)\end{array}$ & $\begin{array}{l}2.473 \\
(12.580)\end{array}$ & $\begin{array}{l}0.6 \\
0.01\end{array}$ \\
\hline 35 & $\begin{array}{l}-0.03 \\
(0.22) \\
\end{array}$ & 0.05 & $\begin{array}{l}-0.597 \\
(4.309)\end{array}$ & $\begin{array}{l}1.233 \\
(12.974)\end{array}$ & $\begin{array}{l}0.02 \\
-0.03 \\
\end{array}$ & $\begin{array}{l}-0.02 \\
(0.25)\end{array}$ & -0.02 & $\begin{array}{l}-1.552 \\
(4.946)\end{array}$ & $\begin{array}{l}4.208 \\
(14.912)\end{array}$ & $\begin{array}{l}0.0: \\
-0.6 \\
\end{array}$ \\
\hline 36 & $\begin{array}{l}-0.35 \\
(0.30)\end{array}$ & 0.01 & $\begin{array}{l}-12.59 \\
(13.991)\end{array}$ & $\begin{array}{l}17.606 \\
(24.704)\end{array}$ & $\begin{array}{l}0.73 \\
-0.01 \\
\end{array}$ & $\begin{array}{l}-0.17 \\
(0.31)\end{array}$ & -0.02 & $\begin{array}{l}-4.739 \\
(13.813)\end{array}$ & $\begin{array}{l}6.064 \\
(24.422)\end{array}$ & $\begin{array}{l}0.1 \text { ، } \\
-0.1\end{array}$ \\
\hline 37 & $\begin{array}{l}-0.95 * \\
(0.34) \\
\end{array}$ & 0.14 & $\begin{array}{l}-7.078 \\
(10.531) \\
\end{array}$ & $\begin{array}{l}0.539 \\
(14.458)\end{array}$ & $\begin{array}{l}3.18 \\
0.11 \\
\end{array}$ & $\begin{array}{c}-1.00^{*} \\
(0.35) \\
\end{array}$ & 0.14 & $\begin{array}{c}-8.599 \\
(11.083) \\
\end{array}$ & $\begin{array}{l}2.098 \\
(15.191)\end{array}$ & $\begin{array}{l}3.2 i \\
0.1:\end{array}$ \\
\hline 38 & $\begin{array}{l}-0.07 \\
(0.25) \\
\end{array}$ & -0.03 & $\begin{array}{l}-1.609 \\
(9.522) \\
\end{array}$ & $\begin{array}{l}4.010 \\
(30.386) \\
\end{array}$ & $\begin{array}{l}0.03 \\
-0.05 \\
\end{array}$ & $\begin{array}{l}0.09 \\
(0.61) \\
\end{array}$ & -0.06 & $\begin{array}{l}-25.061 \\
(20.485) \\
\end{array}$ & $\begin{array}{l}82.898 \\
(66.451) \\
\end{array}$ & $\begin{array}{l}0.7 \\
-0.6 \\
\end{array}$ \\
\hline 39 & $\begin{array}{l}-0.08 \\
(0.13)\end{array}$ & -0.00 & $\begin{array}{l}-0.583 \\
(5.778)\end{array}$ & $\begin{array}{l}-0.256 \\
(6.976)\end{array}$ & $\begin{array}{l}0.13 \\
-0.03\end{array}$ & $\begin{array}{l}-0.03 \\
(0.13)\end{array}$ & -0.02 & $\begin{array}{l}2.633 \\
(5.367)\end{array}$ & $\begin{array}{l}-3.488 \\
(6.443)\end{array}$ & $\begin{array}{l}0.1 \text { : } \\
-0.1\end{array}$ \\
\hline & $2 / 20$ & fficients & $0 / 20$ & $0 / 20$ & & $3 / 20$ & & $0 / 20$ & $2 / 20$ & \\
\hline & $6 / 14$ & & $16 / 4$ & $16 / 4$ & & $8 / 12$ & & $3 / 17$ & $16 / 4$ & \\
\hline
\end{tabular}

$*$ significant at 5 percent. $* *$ significant at 10 percent. 